Supporting Information

\title{
Integration of Recognition Elements with Macromolecular Scaffolds: Effects on Polymer Self-Assembly in the Solid-State
}

Roy Shenhar, Amitav Sanyal, Oktay Uzun, Hiroshi Nakade, and Vincent M. Rotello

Department of Chemistry, University of Massachusetts, Amherst, MA 01003

$\mathrm{PS} / \mathrm{CMS}(25,50 \%)-\mathrm{GPC}$

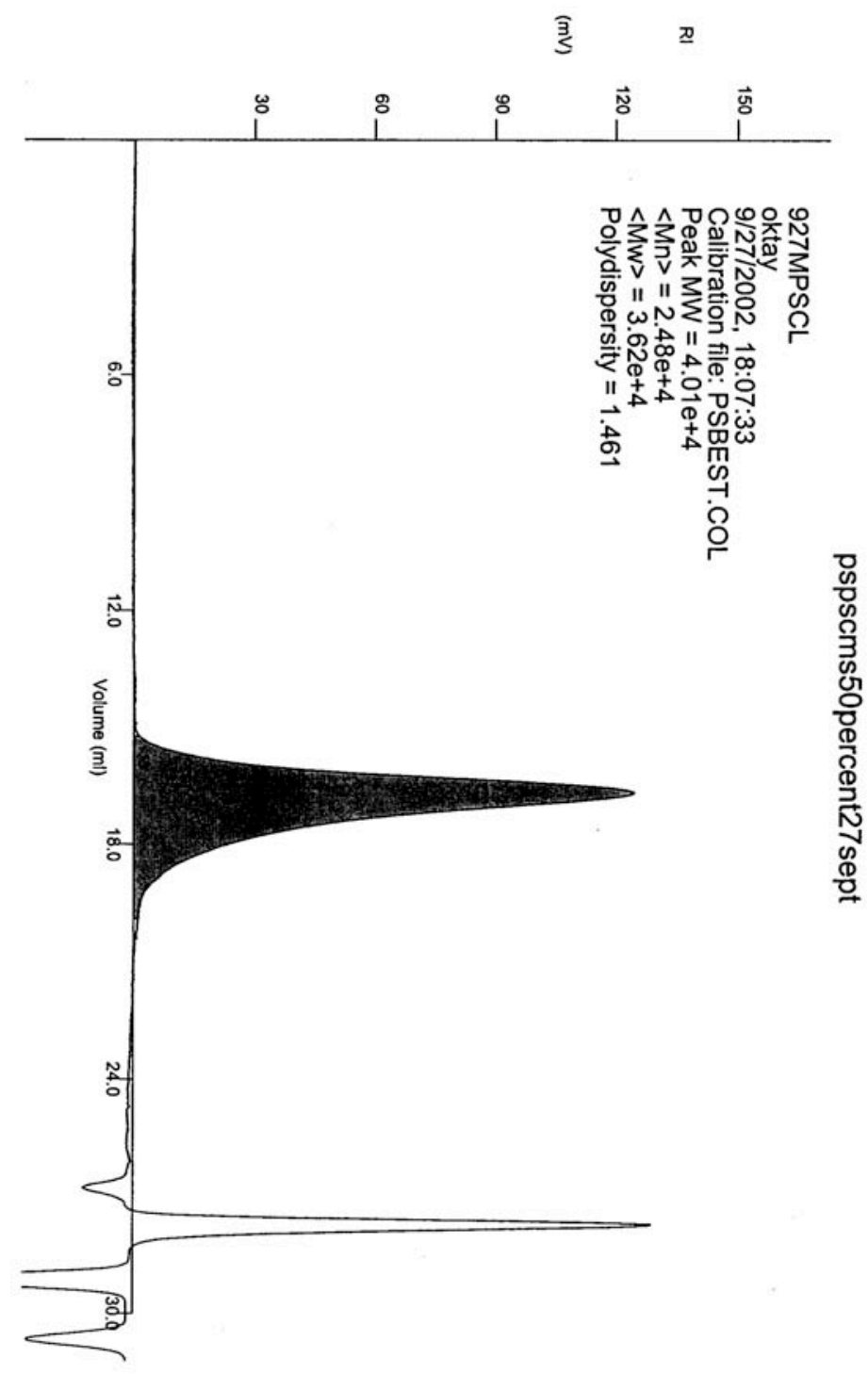




\section{PS/CMS(25,50\%) - NMR}
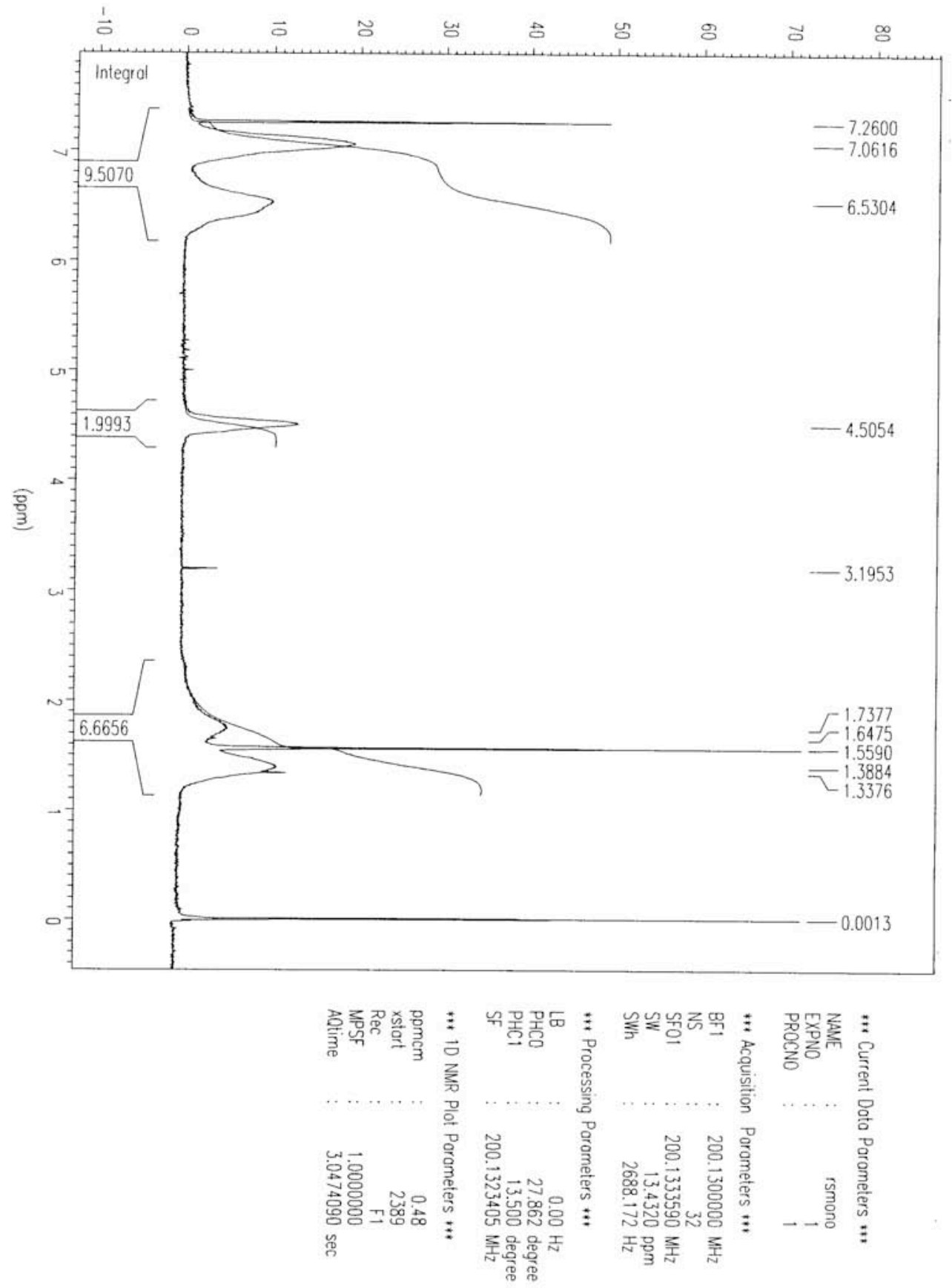
S3

PS/Anth(25,50\%) - NMR

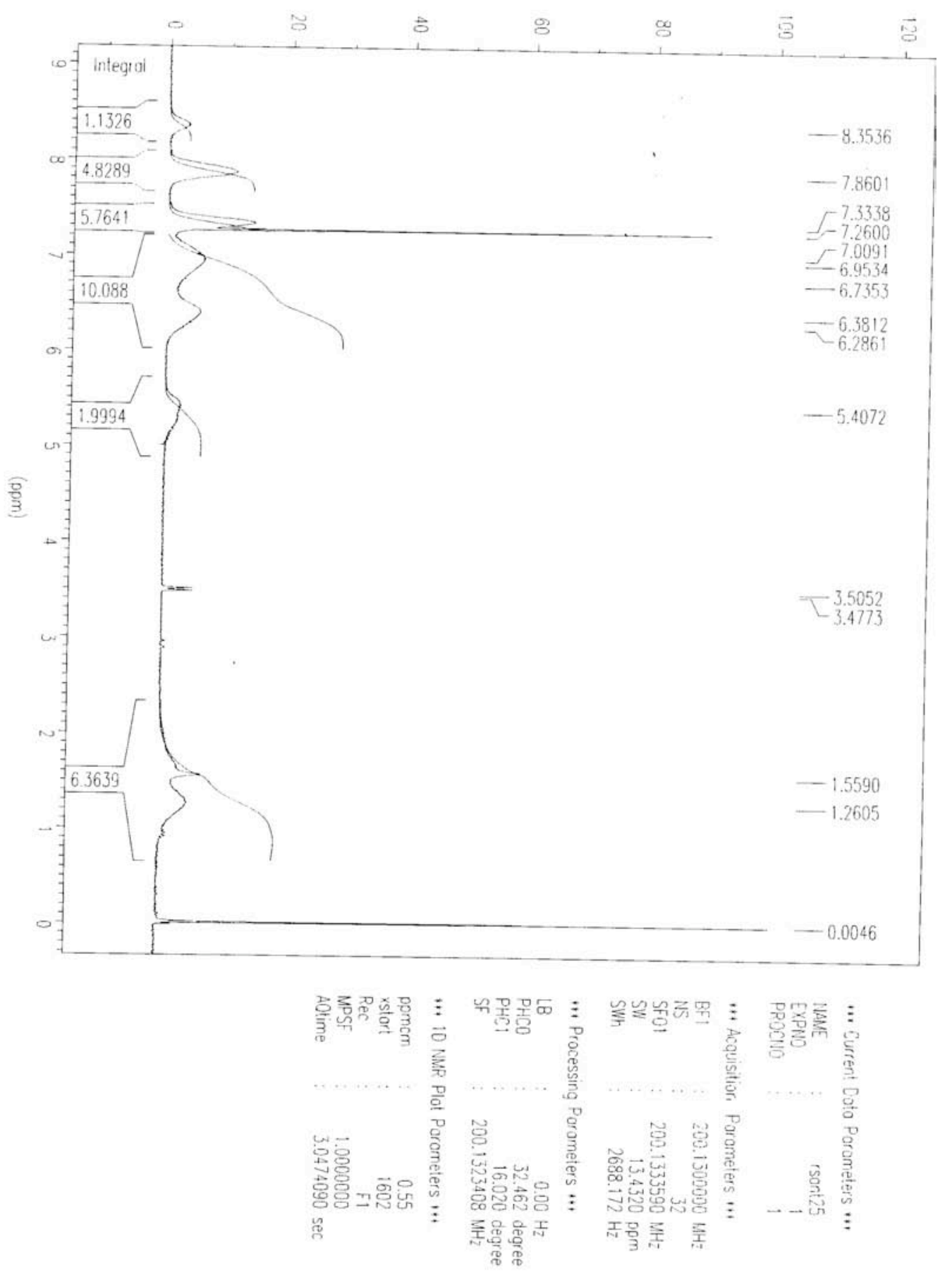




$$
\text { PS/Pyr(25,50\%) - NMR }
$$
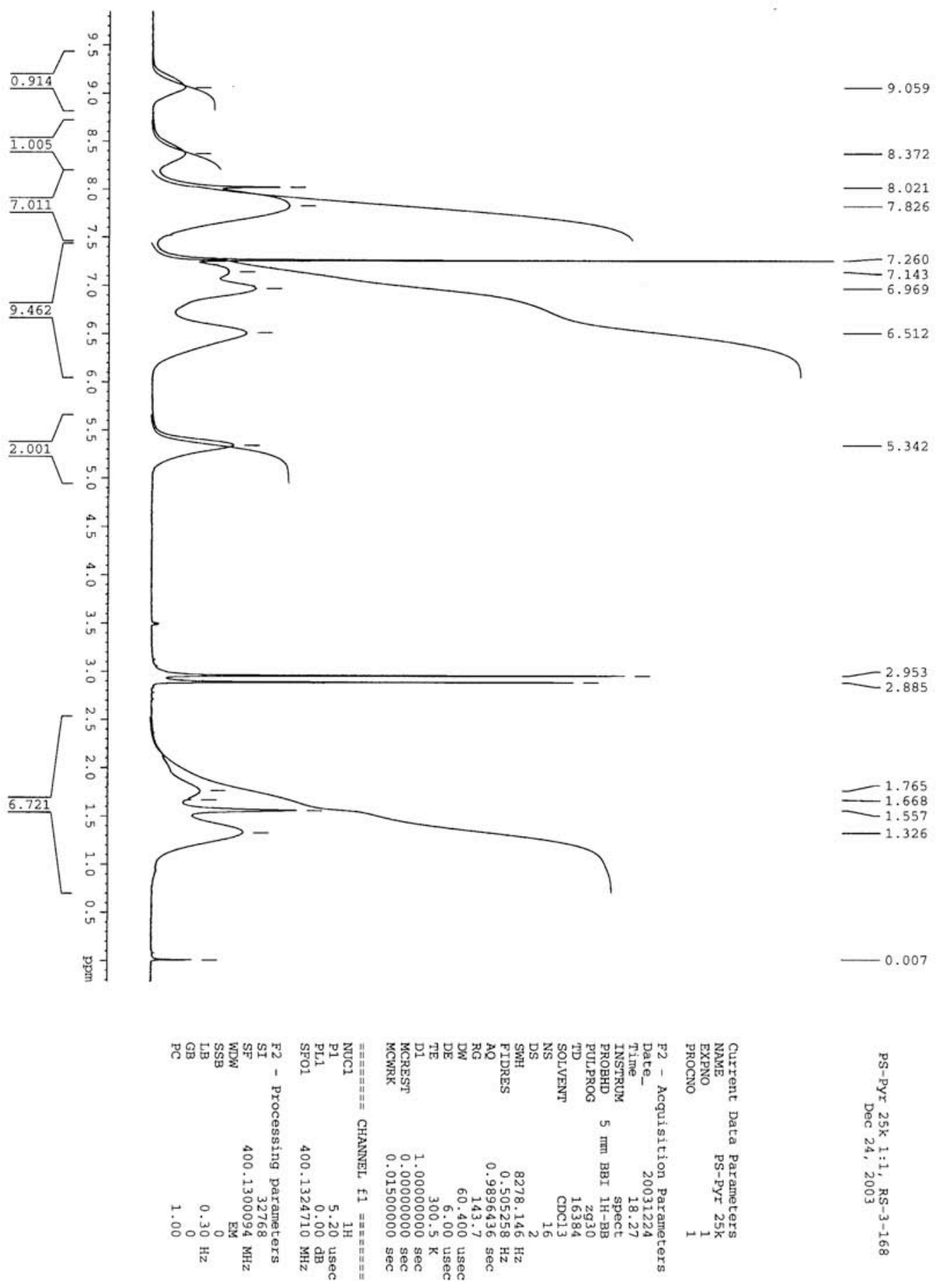


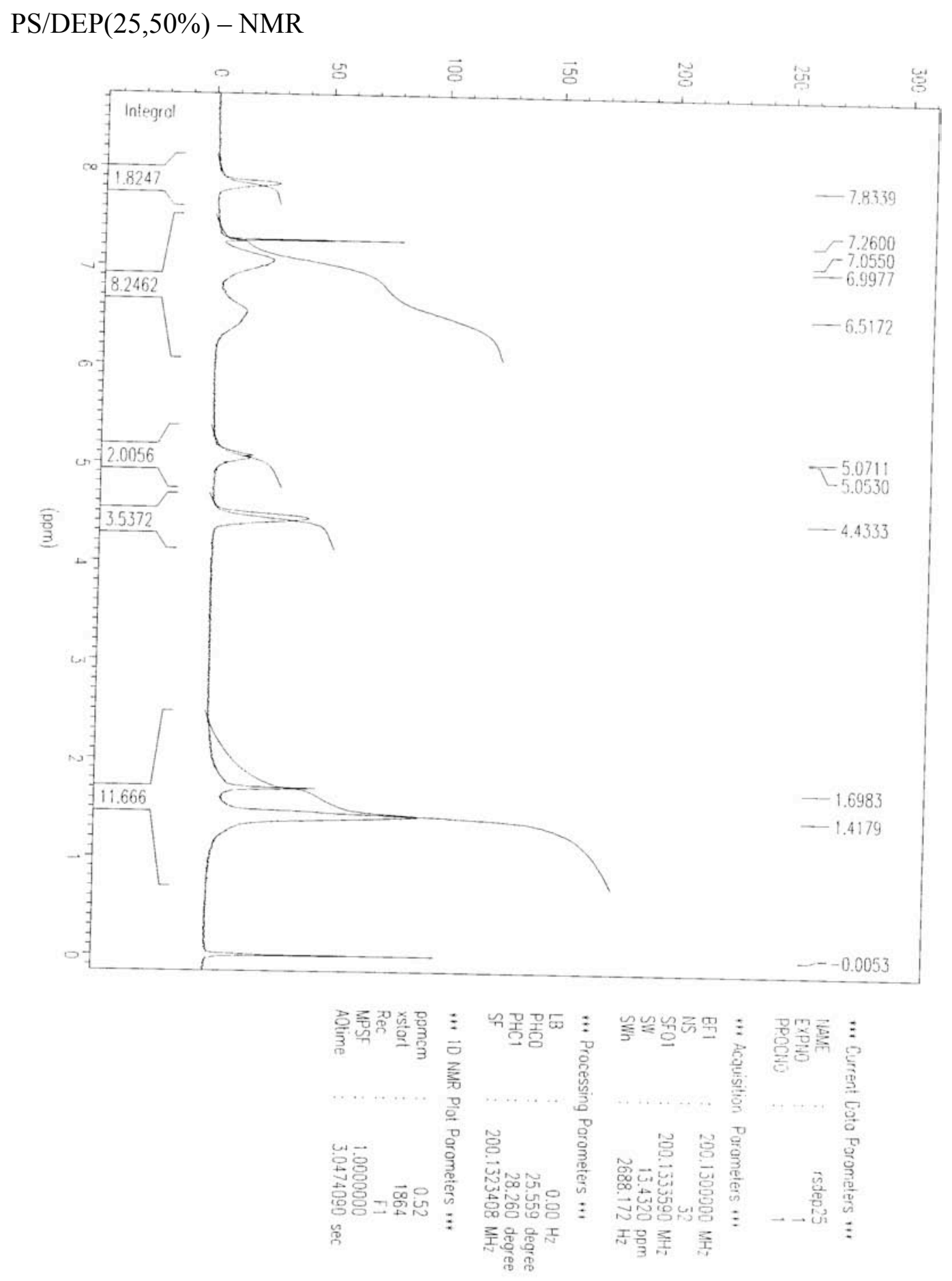




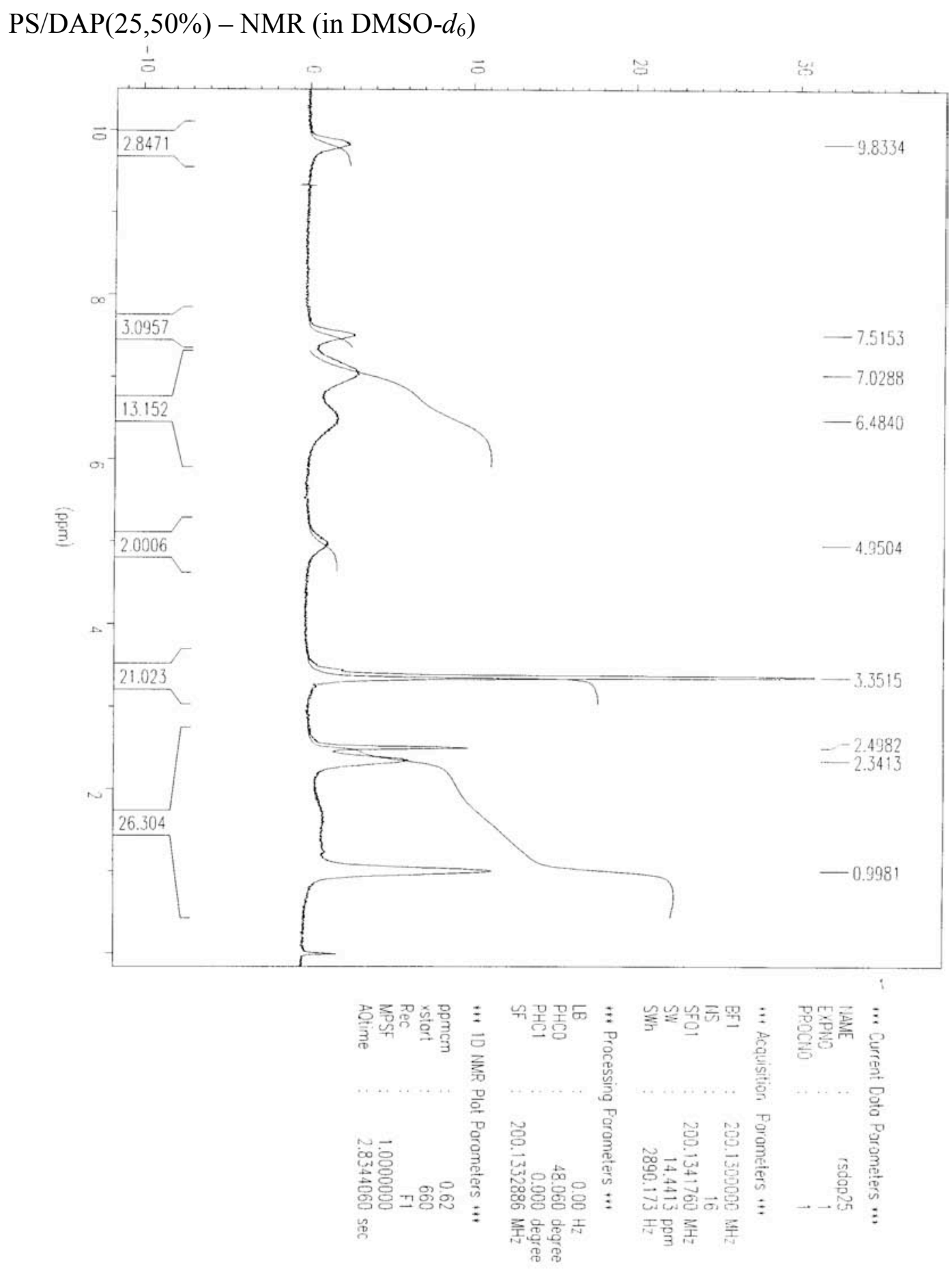




\section{PS/CMS(27:13,17\%) - GPC}

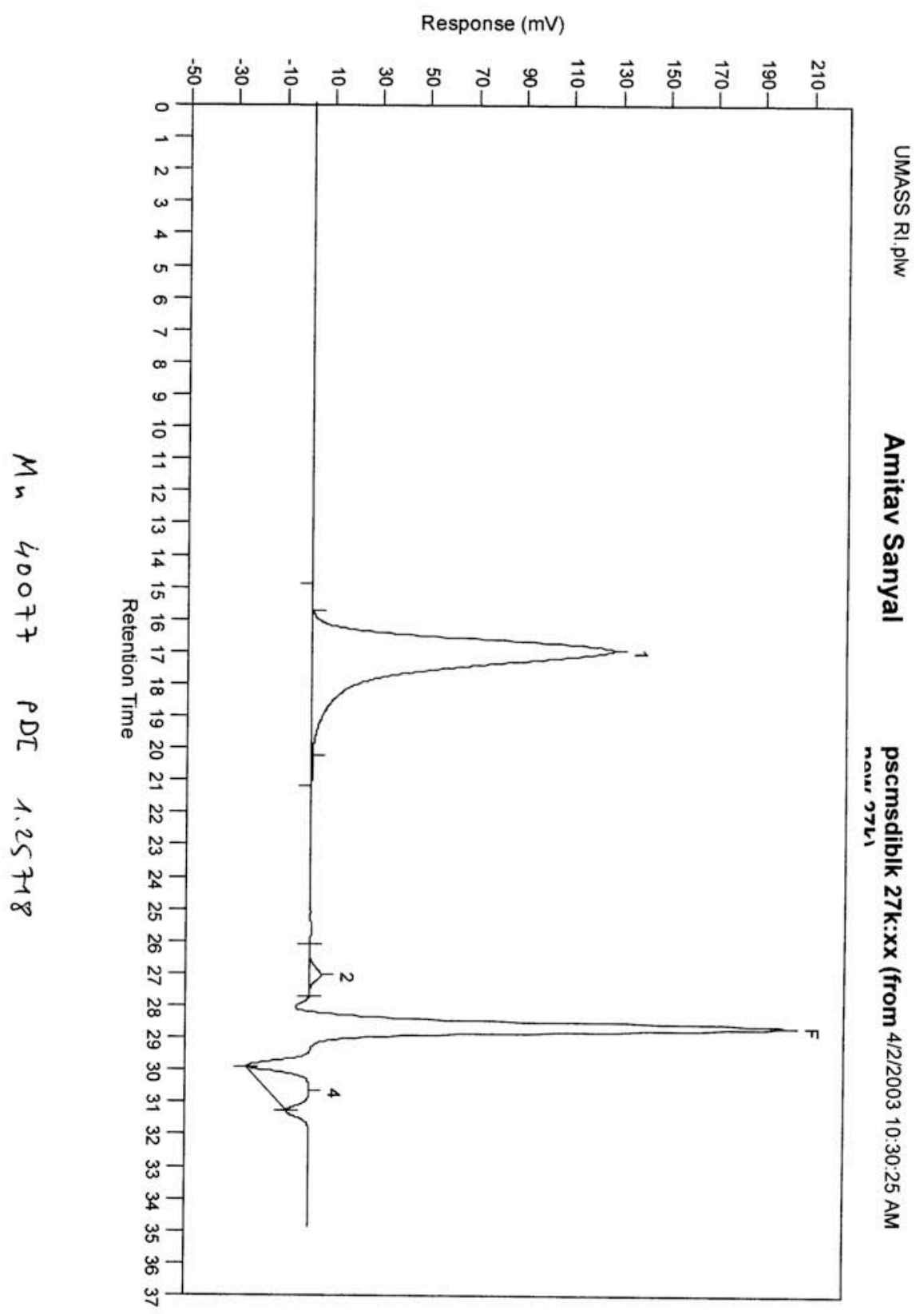




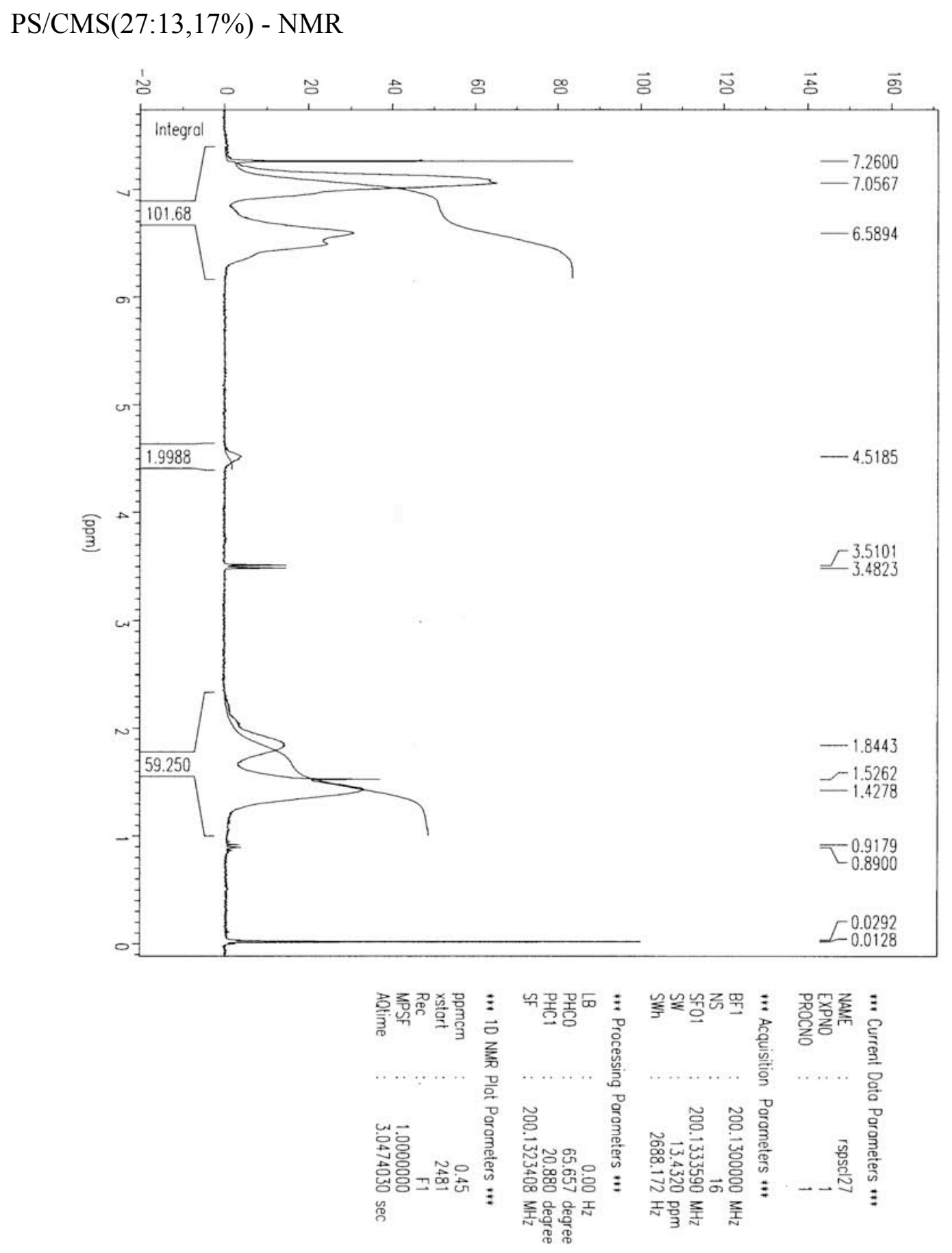




\section{PS/Anth(27:13,17\%) - NMR}

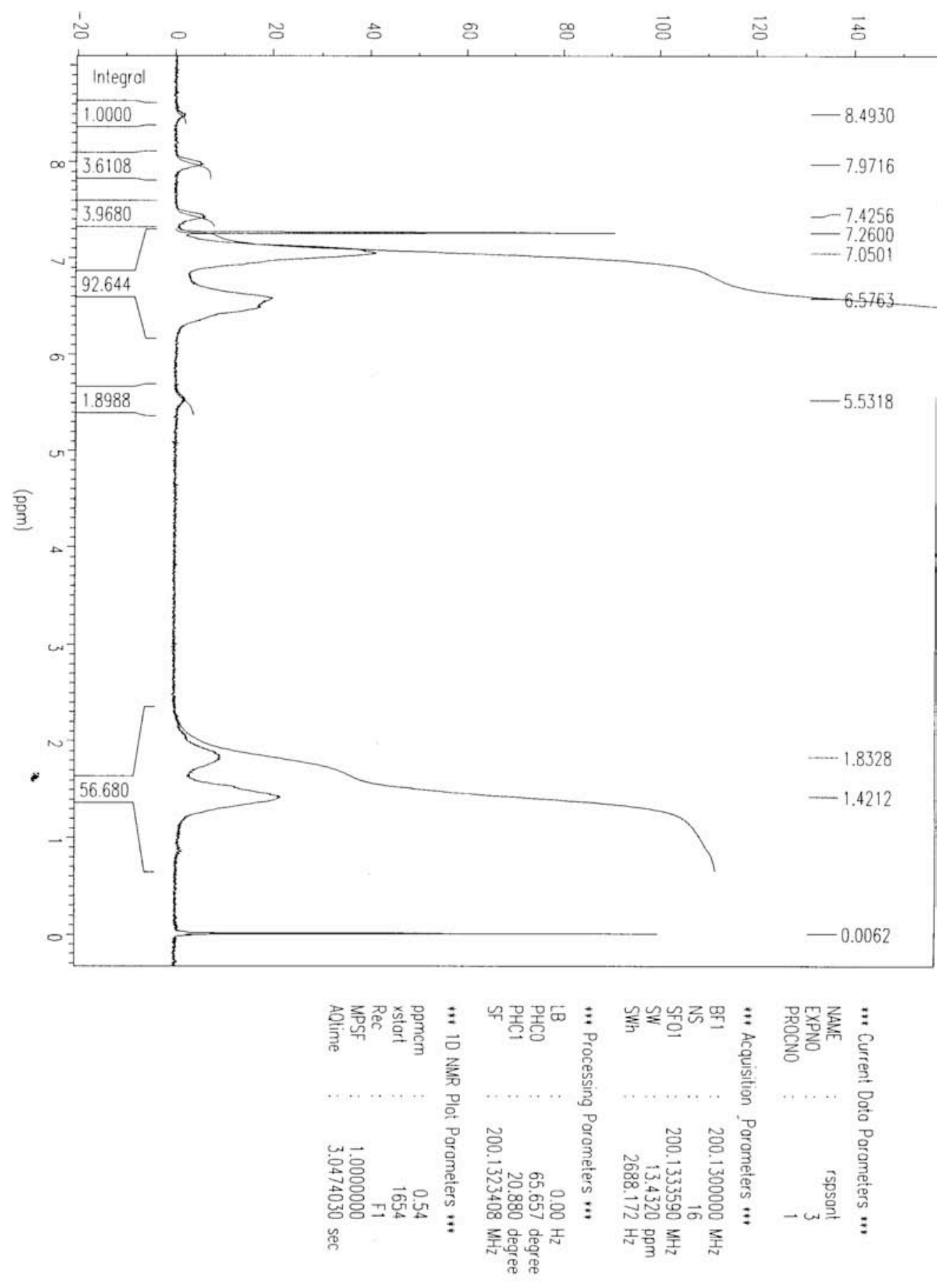




\section{PS/Pyr(27:13,17\%) - NMR}
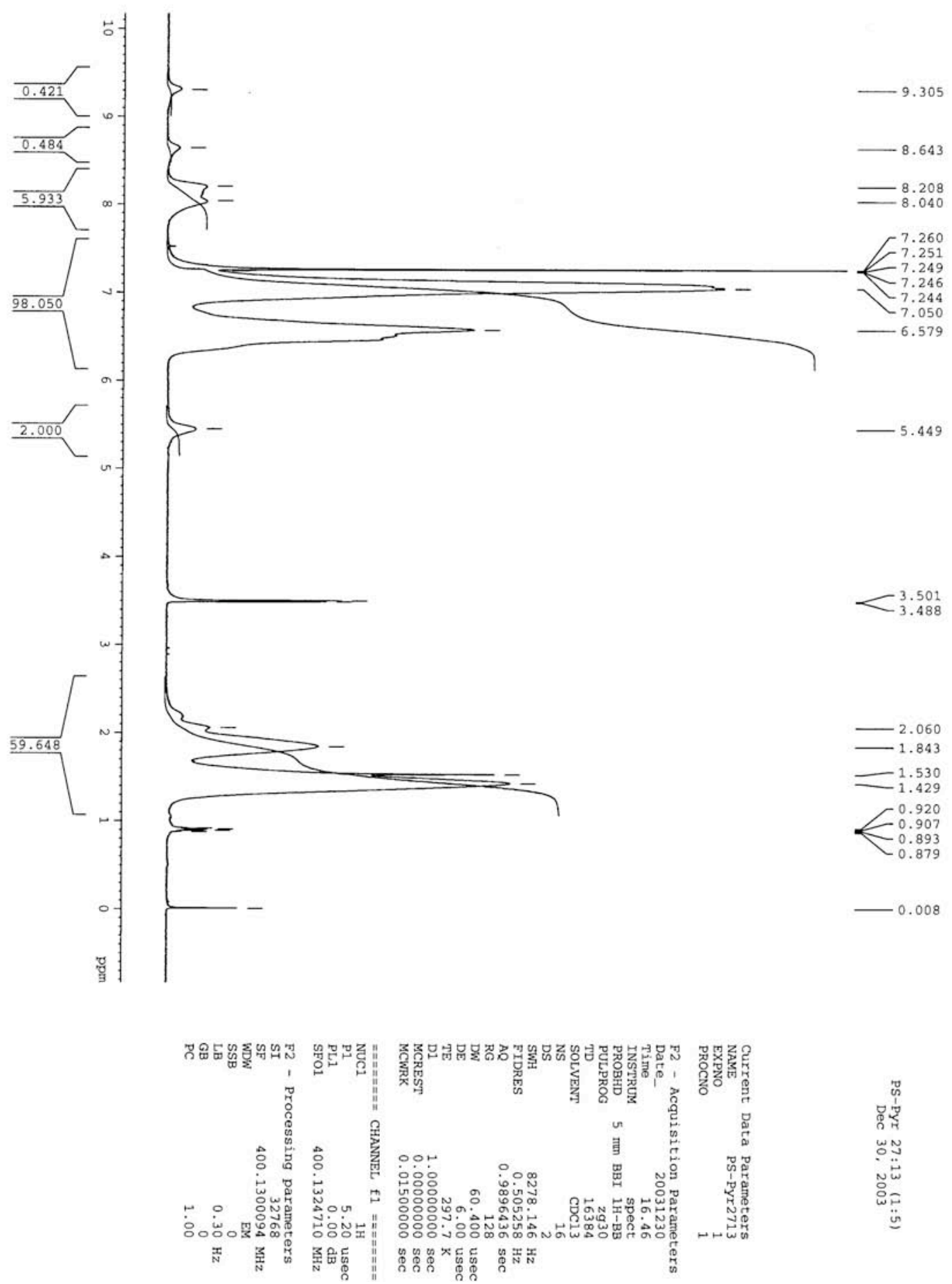

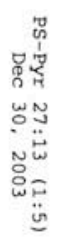


S11
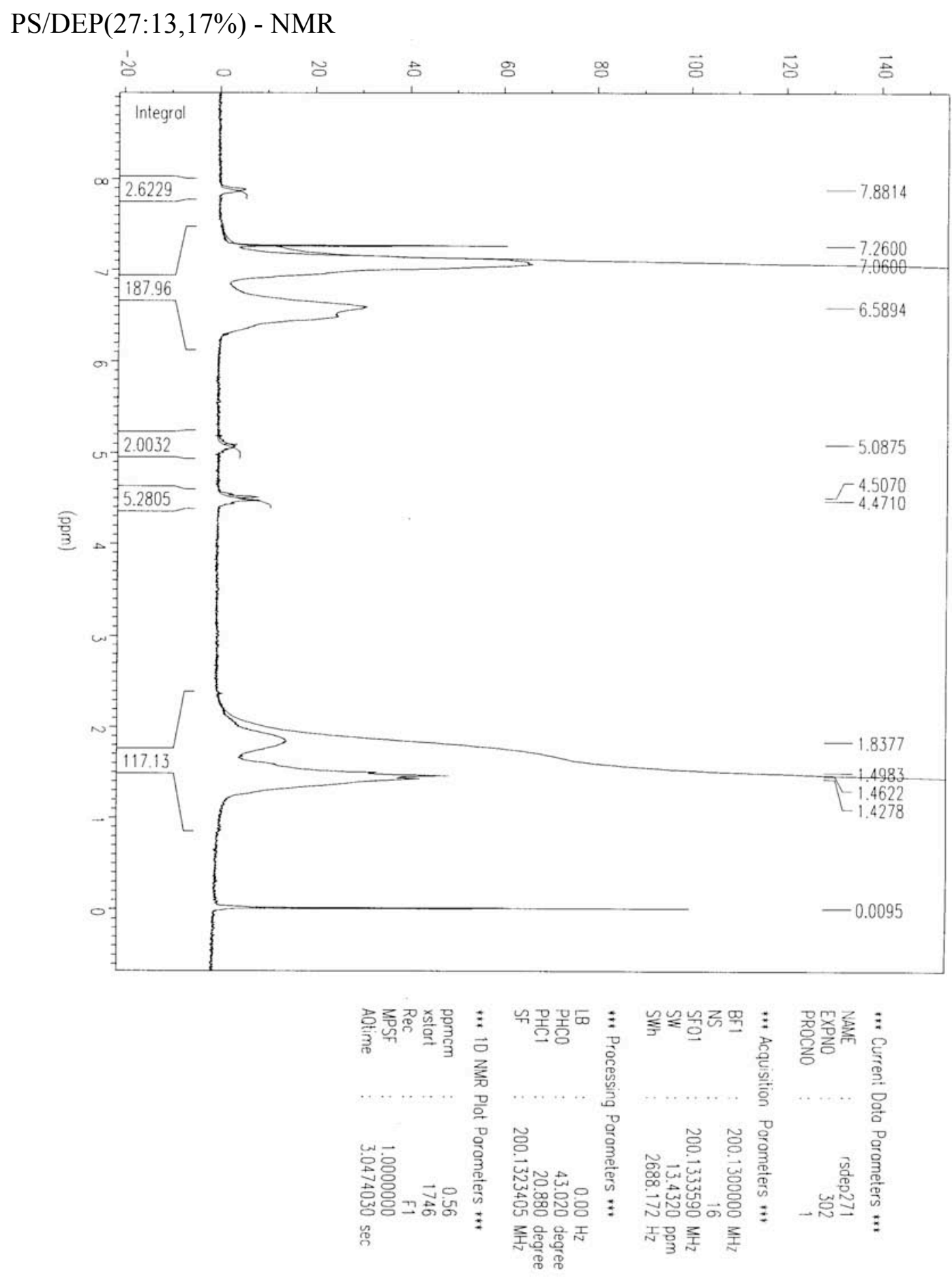
S12

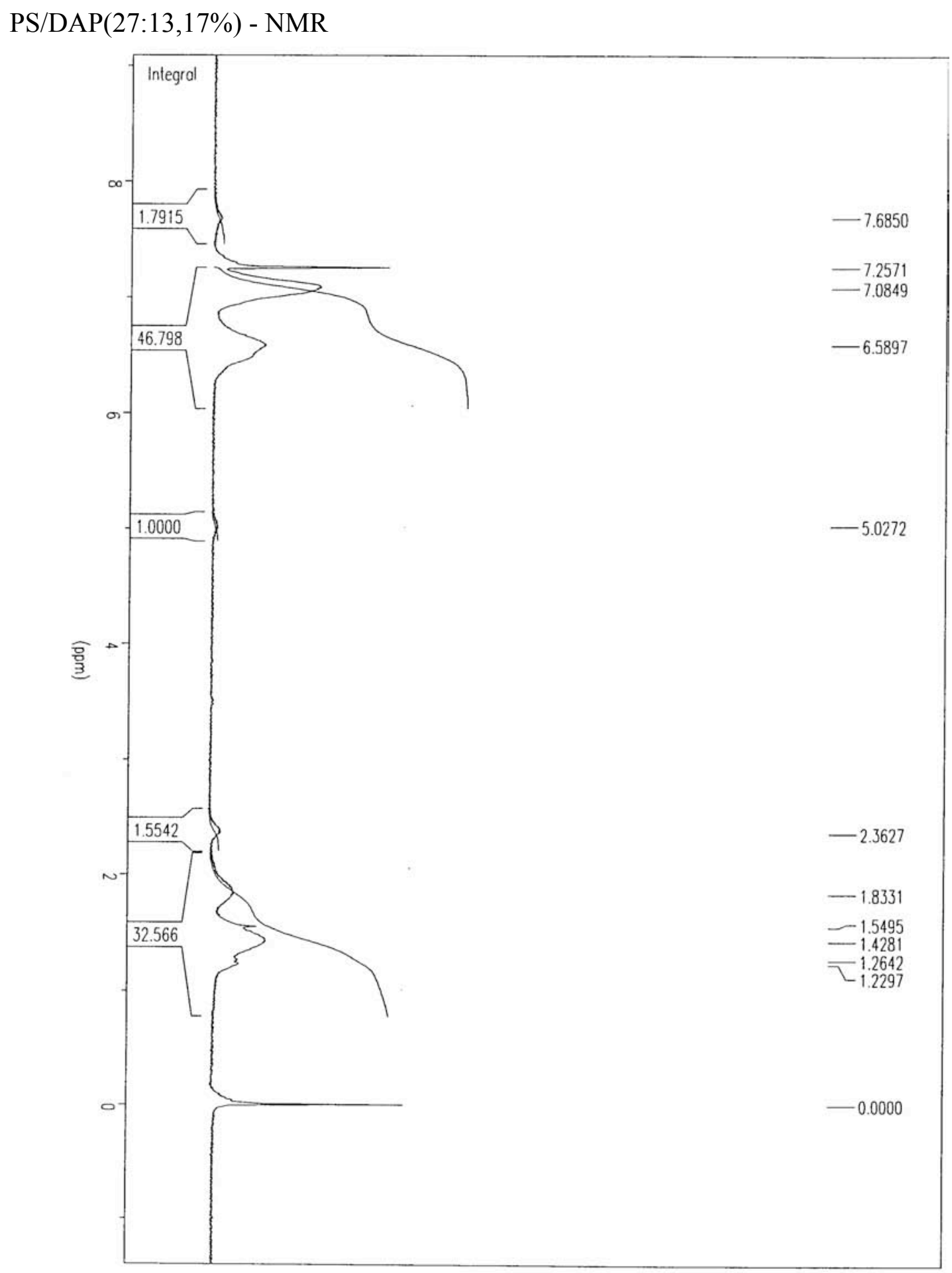


S13

PS/CMS(27:13,25\%) - GPC

Response (mV)

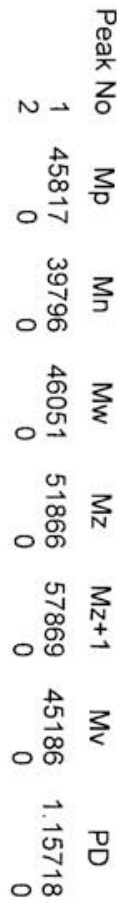

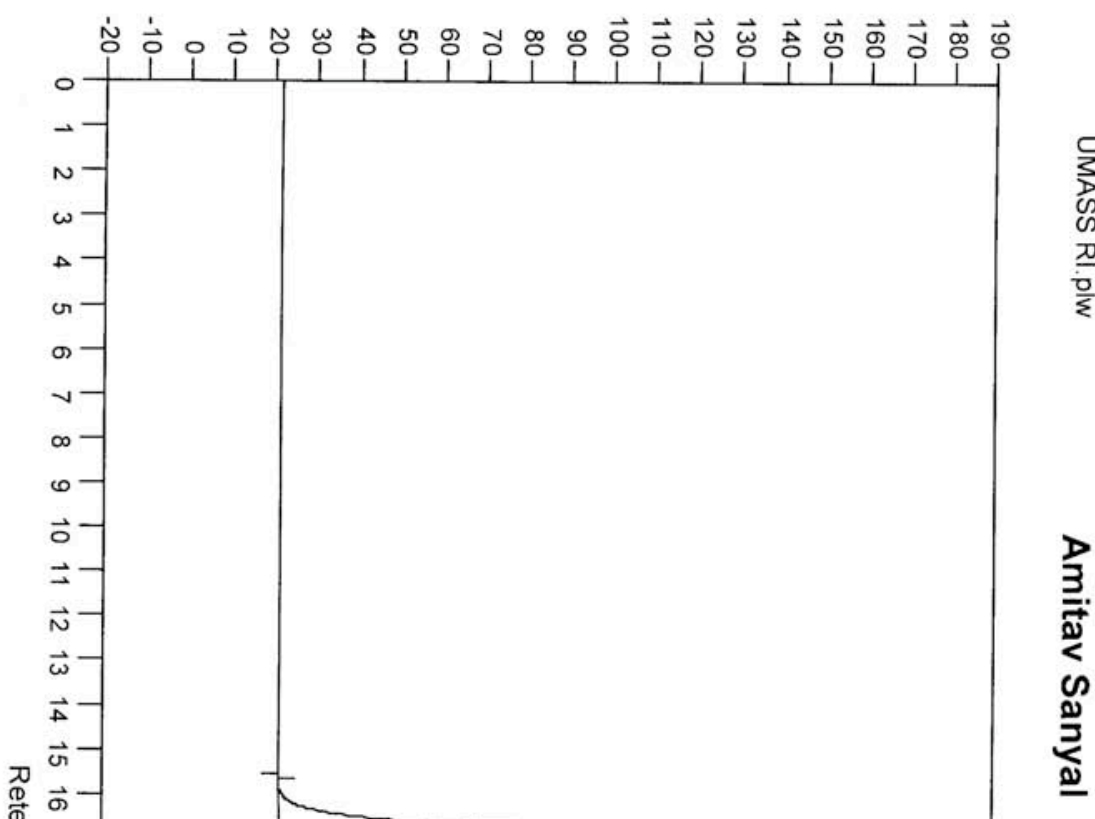

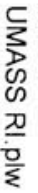

ֻ

D
$\dot{1}$
$\dot{\vec{D}}$
o
$\dot{1}$

o
o
N
0
W
$\overrightarrow{0}$
0
0
0
0
3
3 
S14

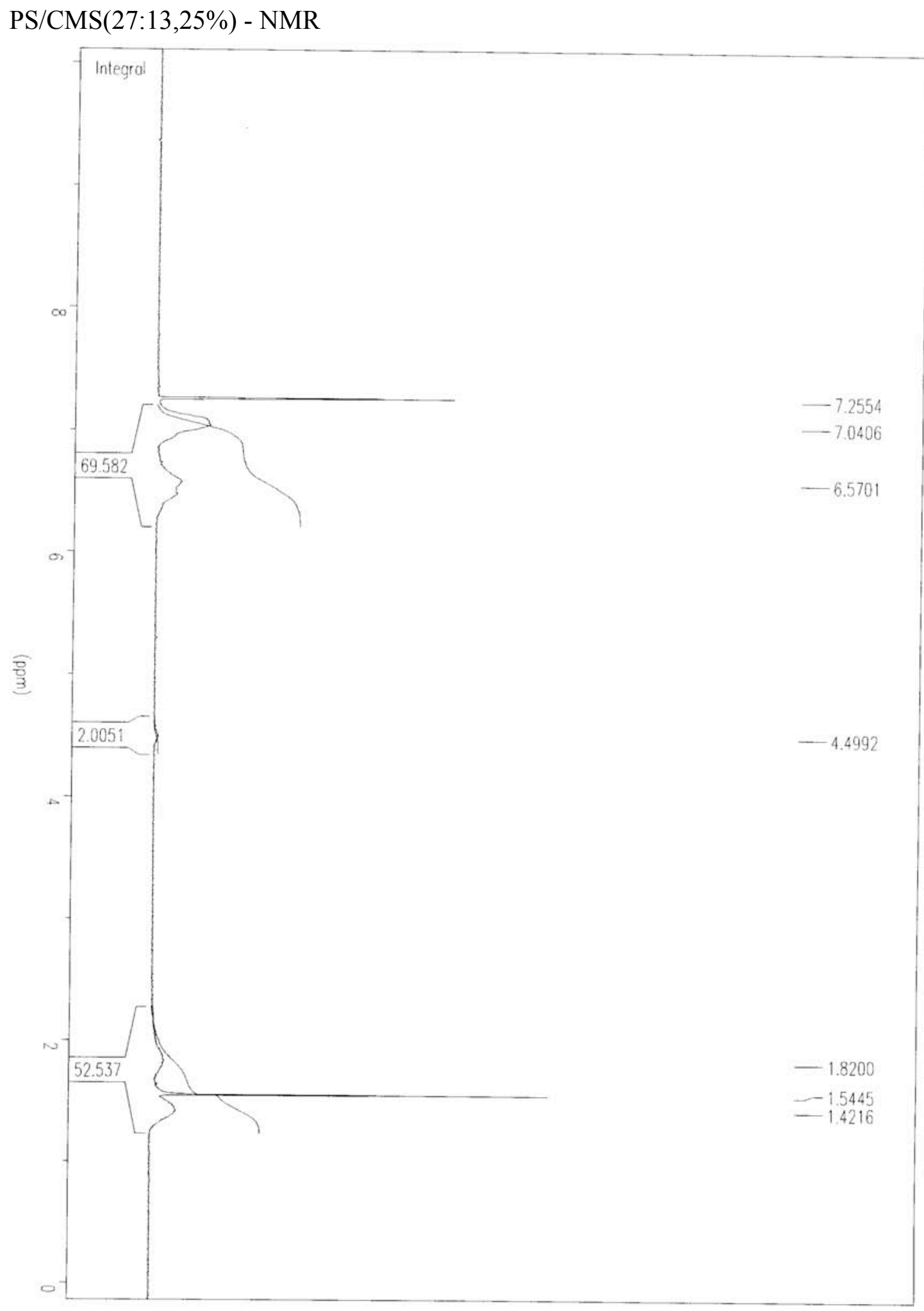


S15

PS/Anth(27:13,25\%) - NMR

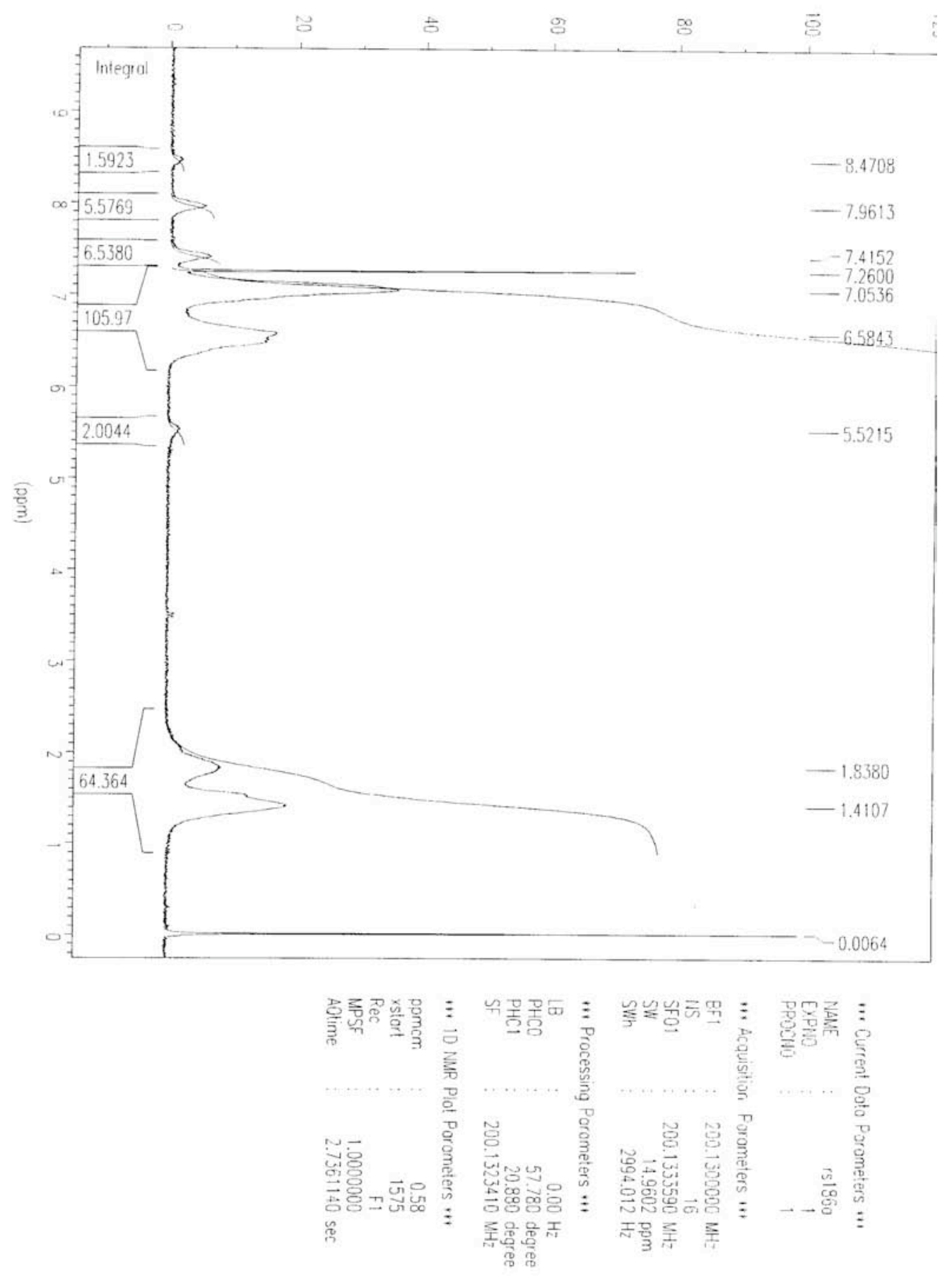




\section{PS/Pyr(27:13,25\%) - NMR}
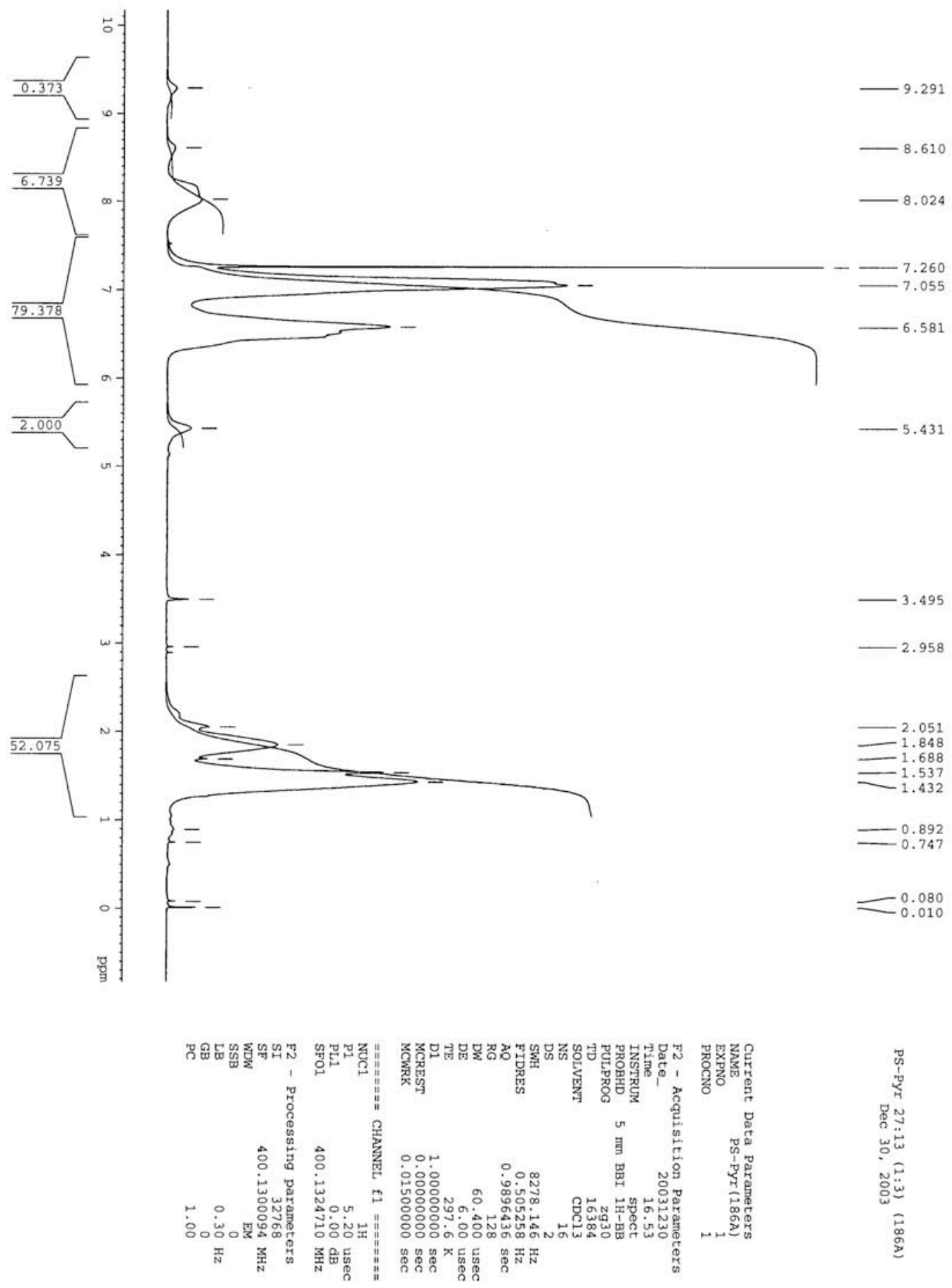


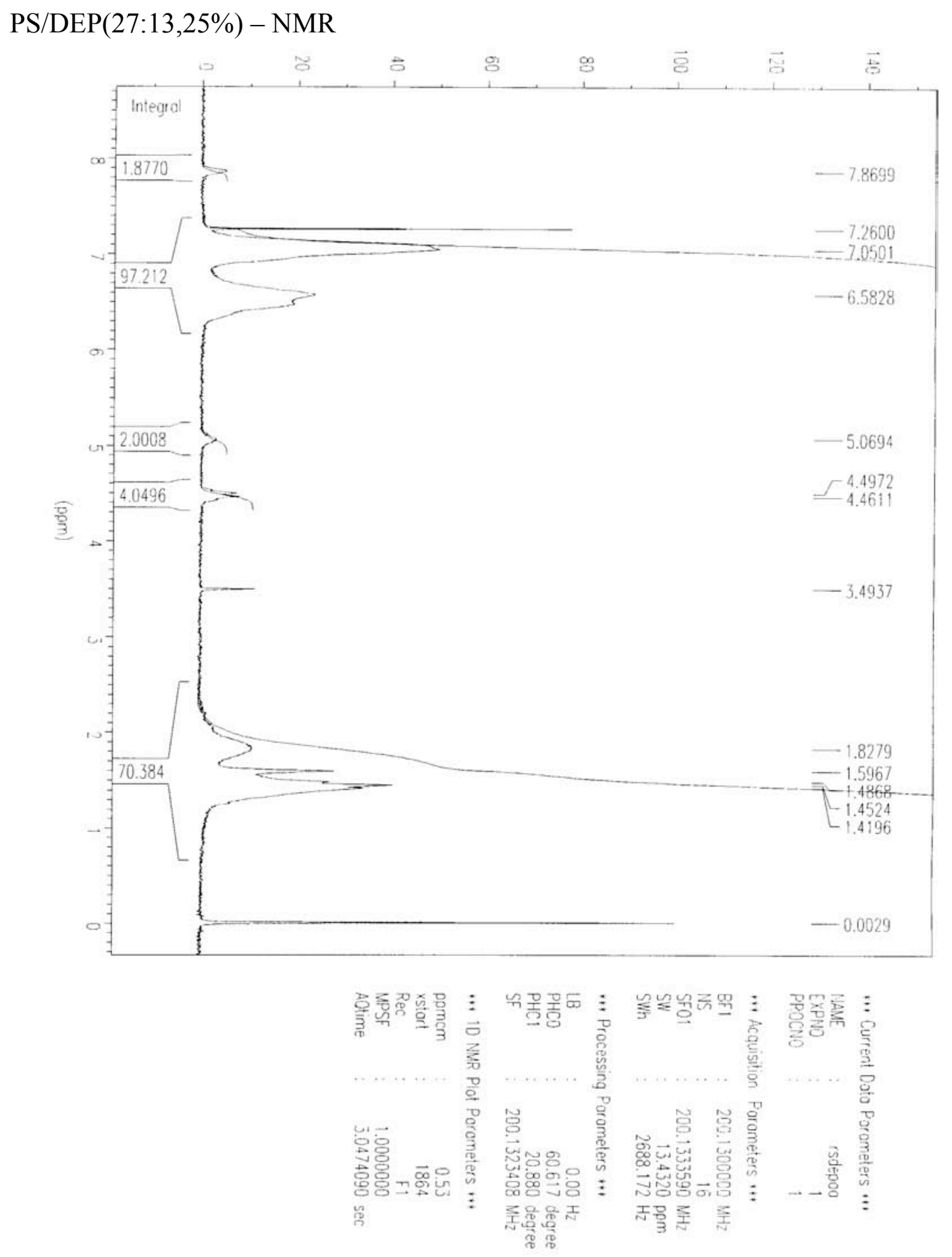


S18

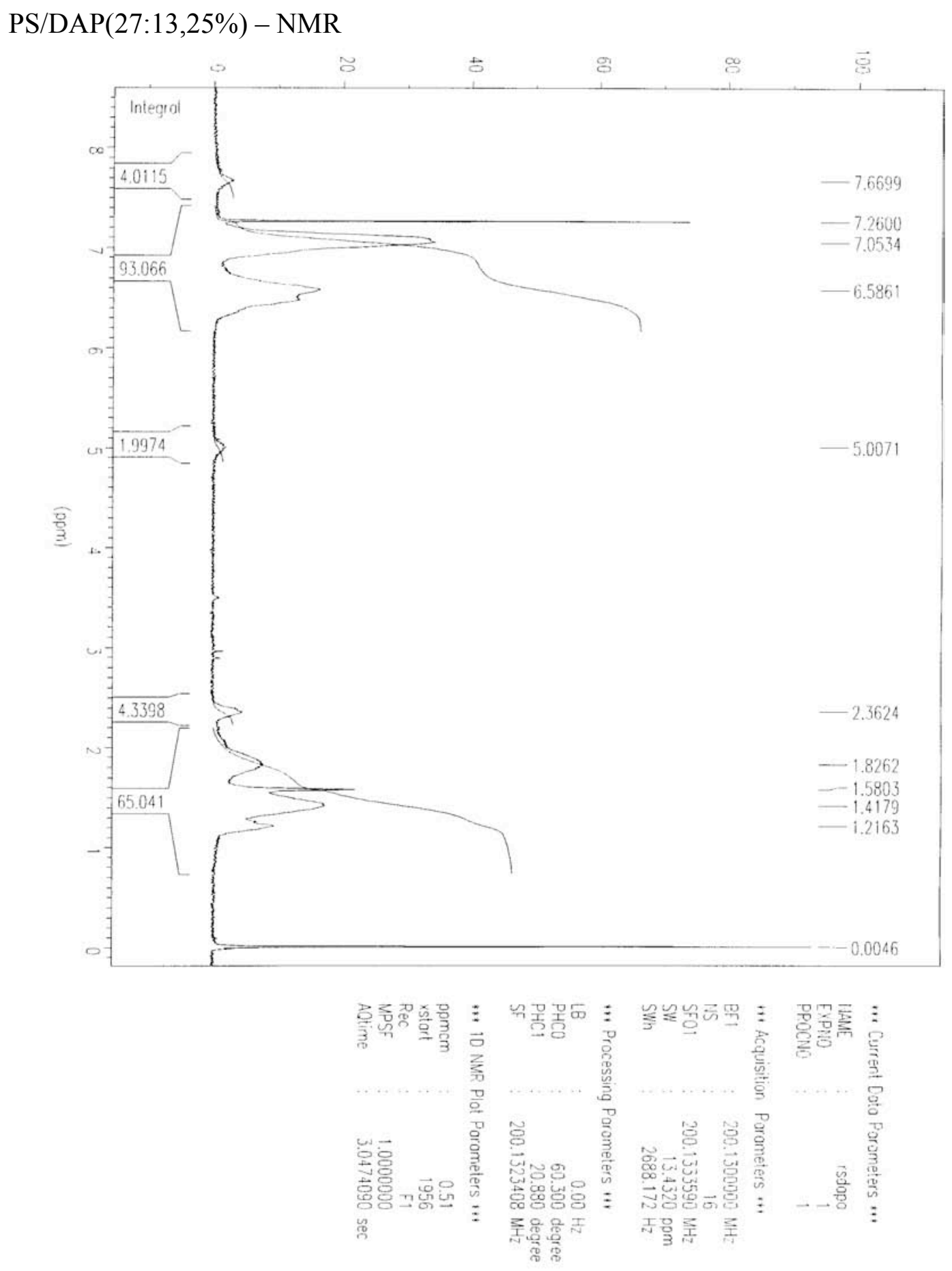


PS/CMS(28:13,40\%) - GPC

Response (mV)

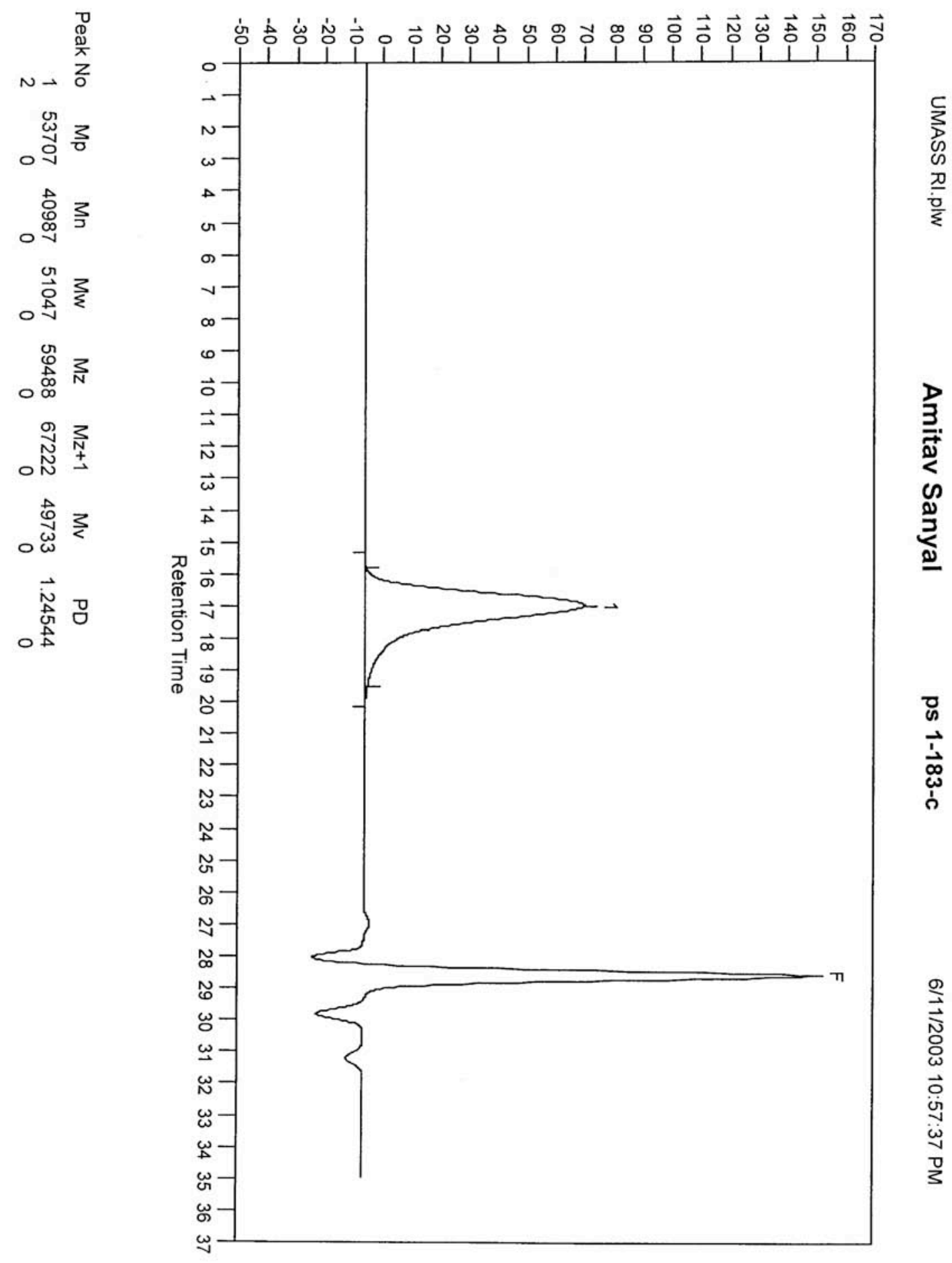




\section{PS/CMS(28:13,40\%) - NMR}

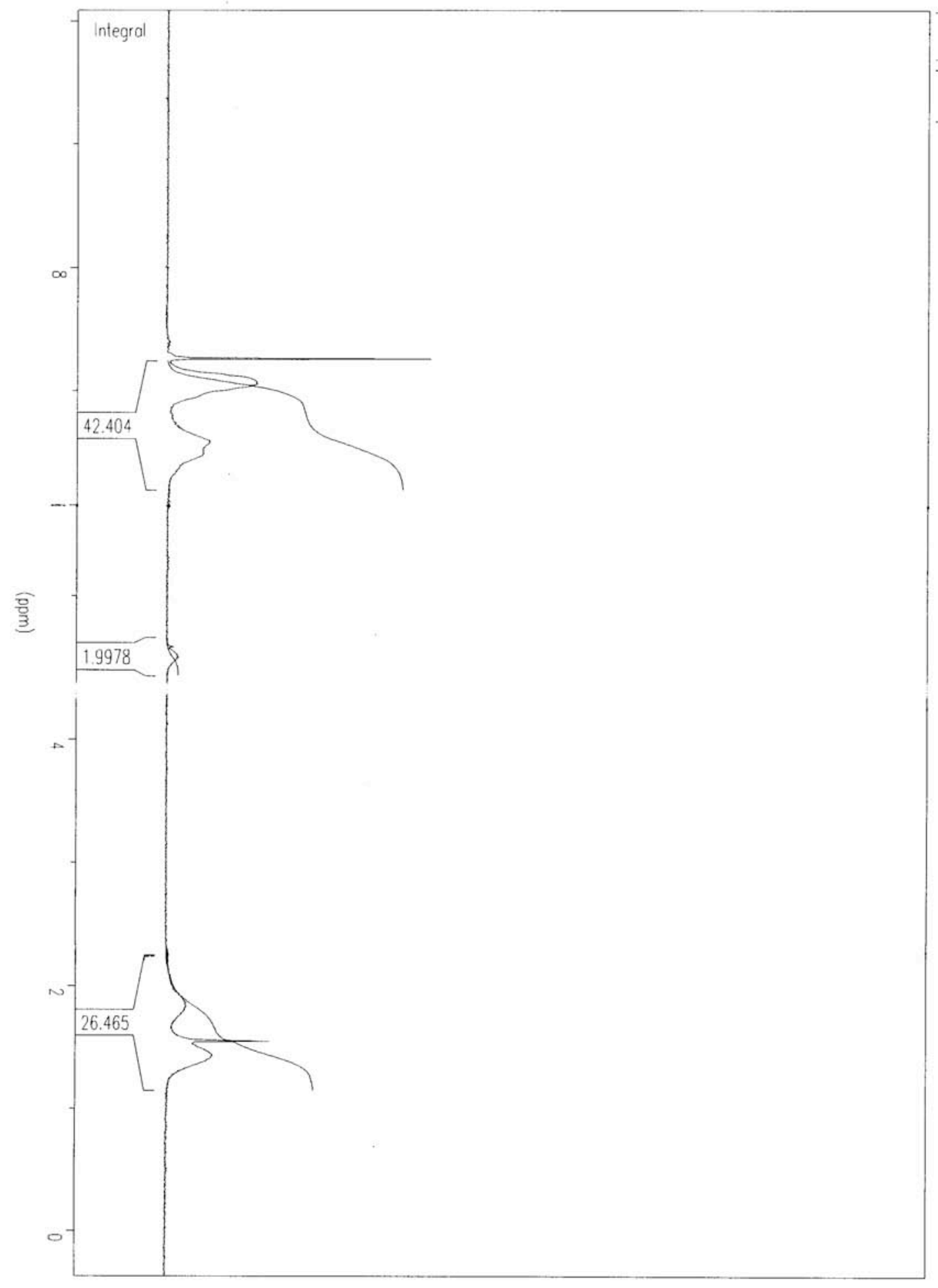




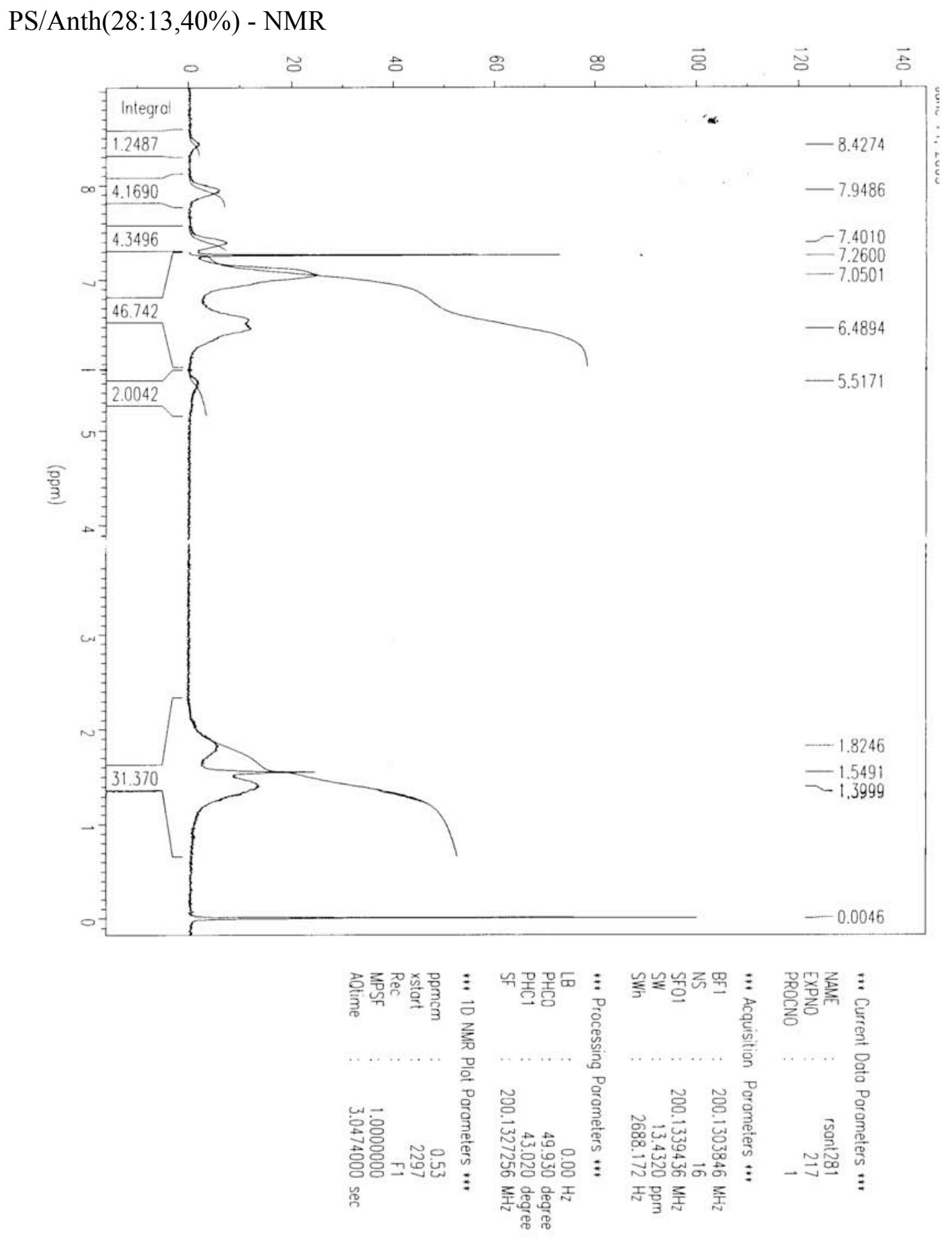




\section{PS/Pyr(28:13,40\%) - NMR}
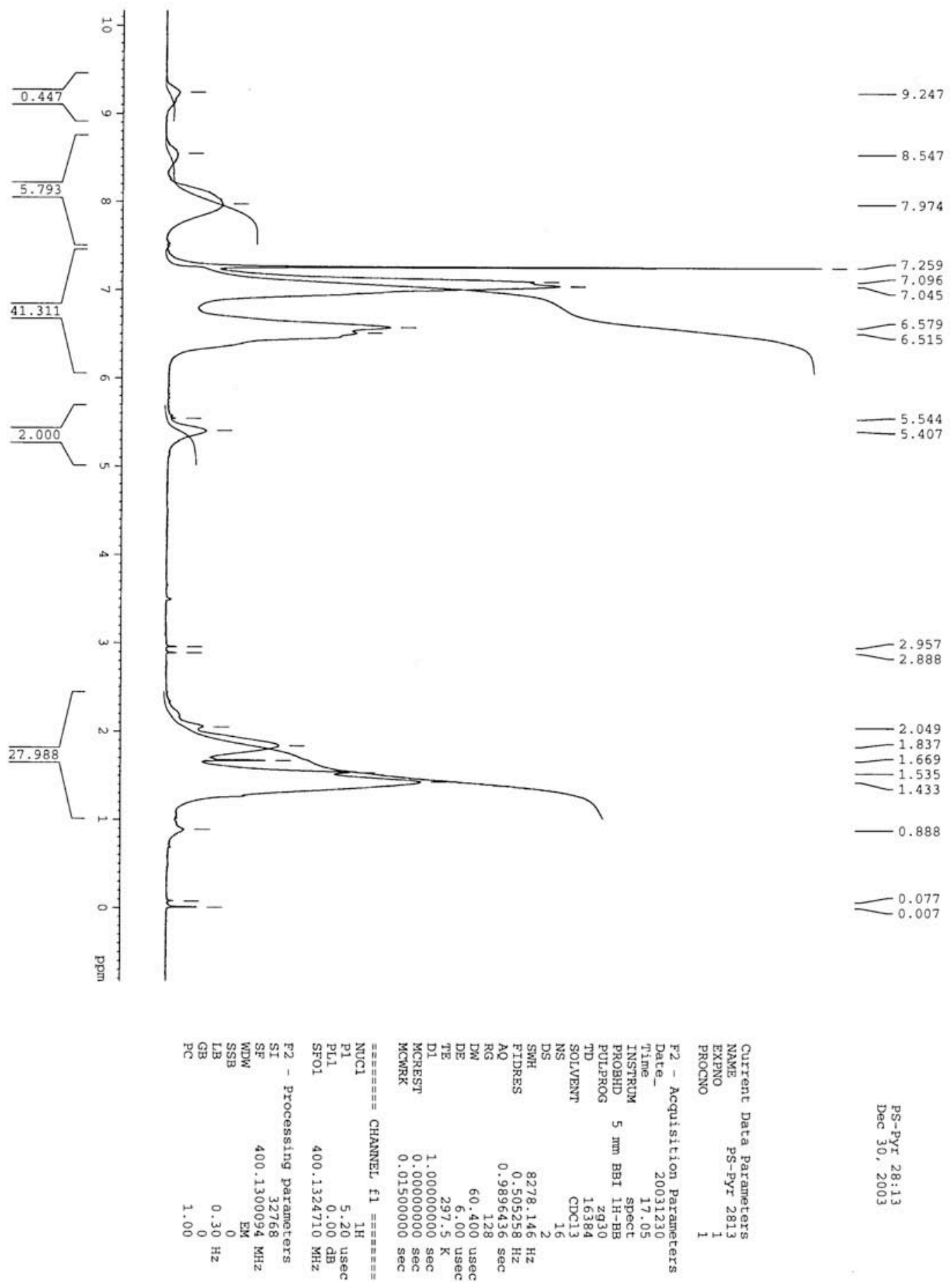
S23

PS/DEP(28:13,40\%) - NMR
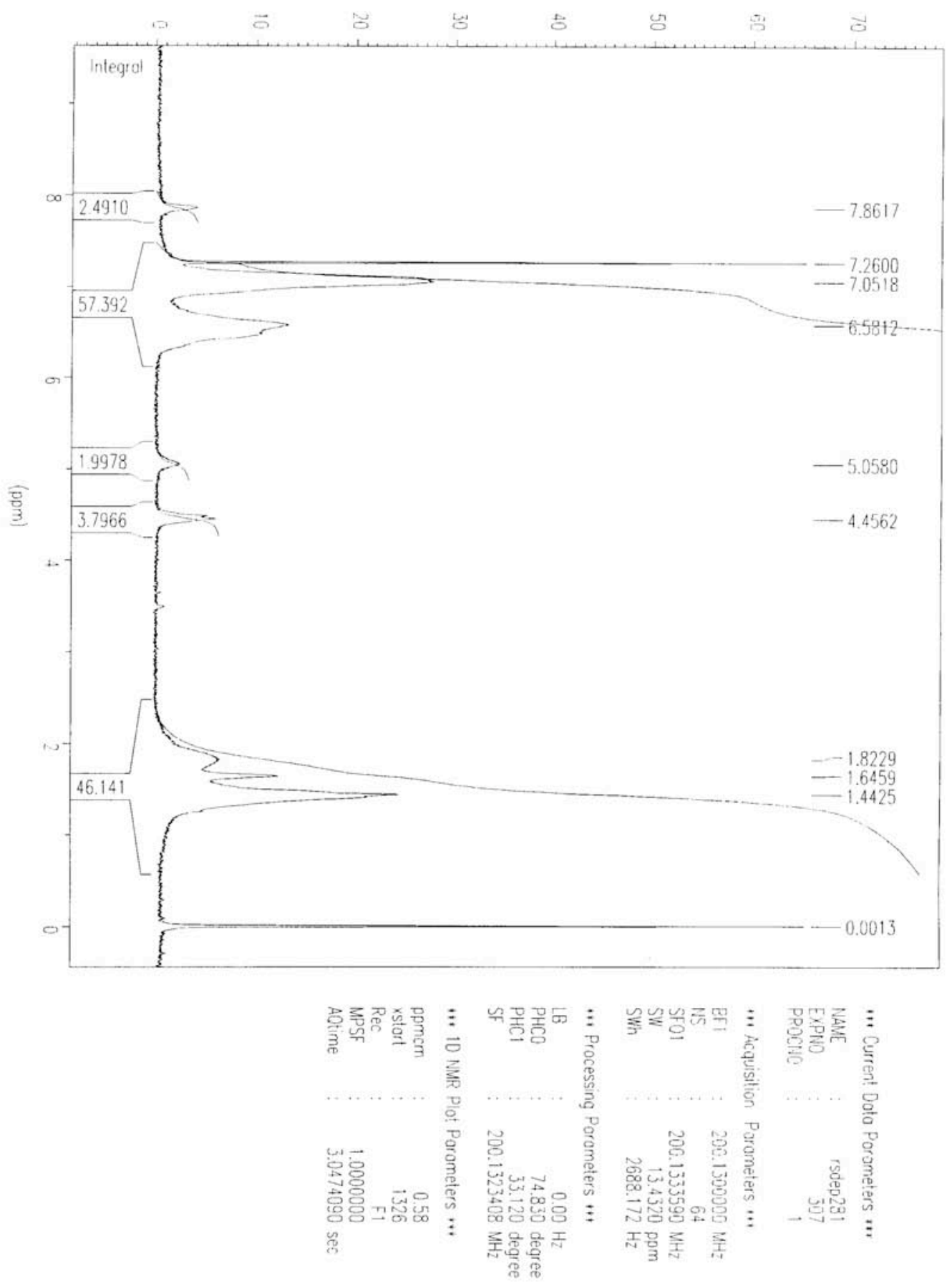


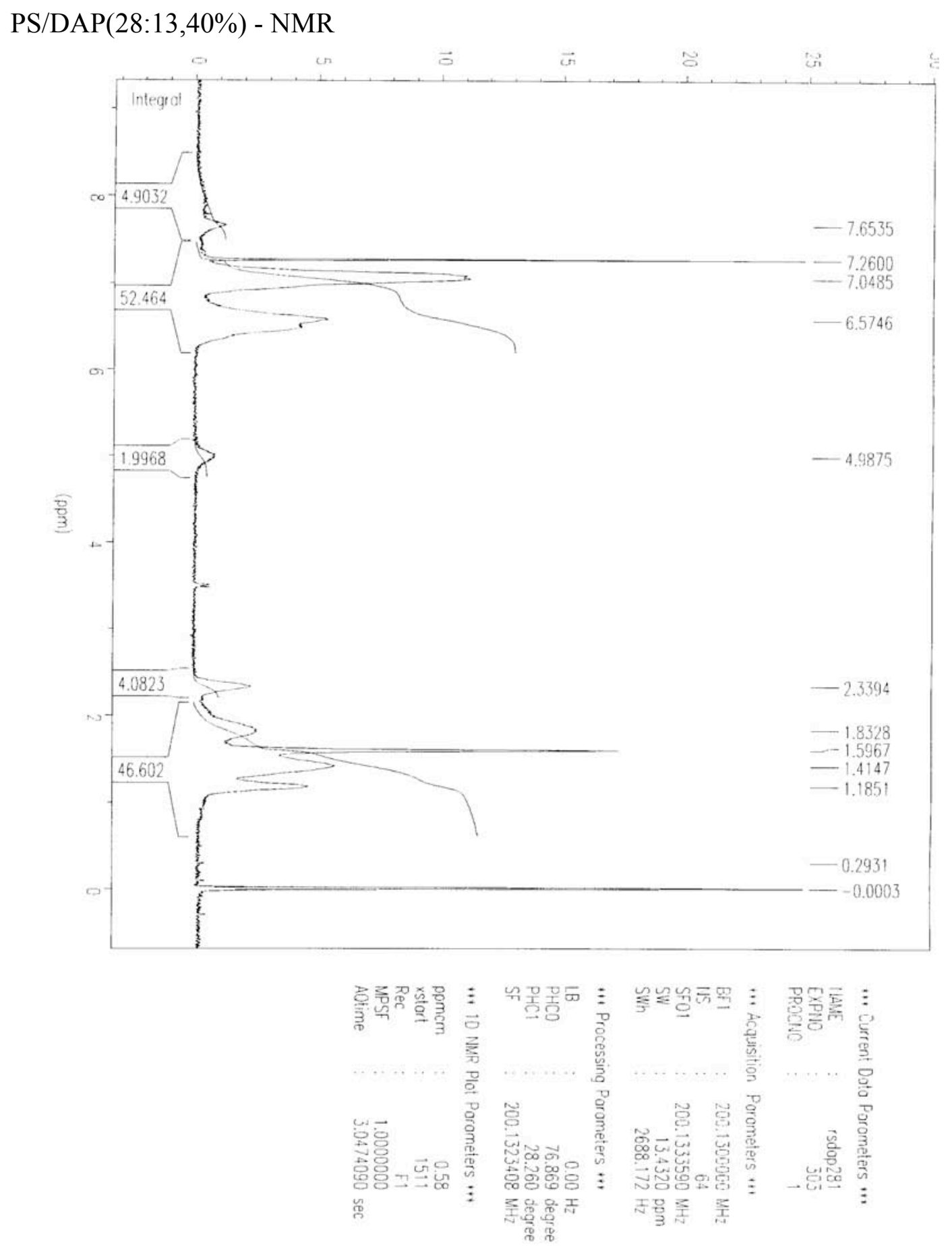


PS/CMS(27:20,25\%) - GPC

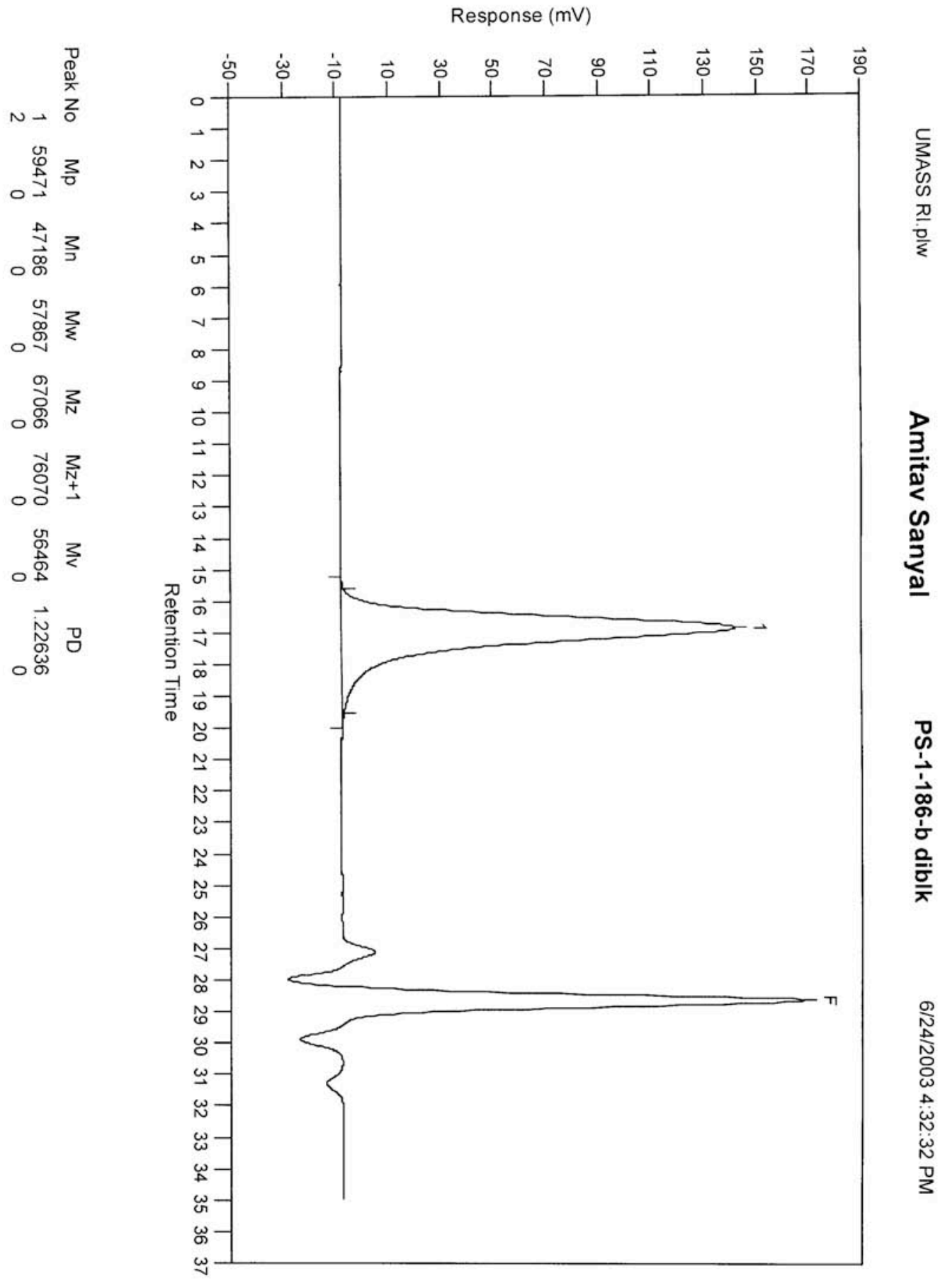




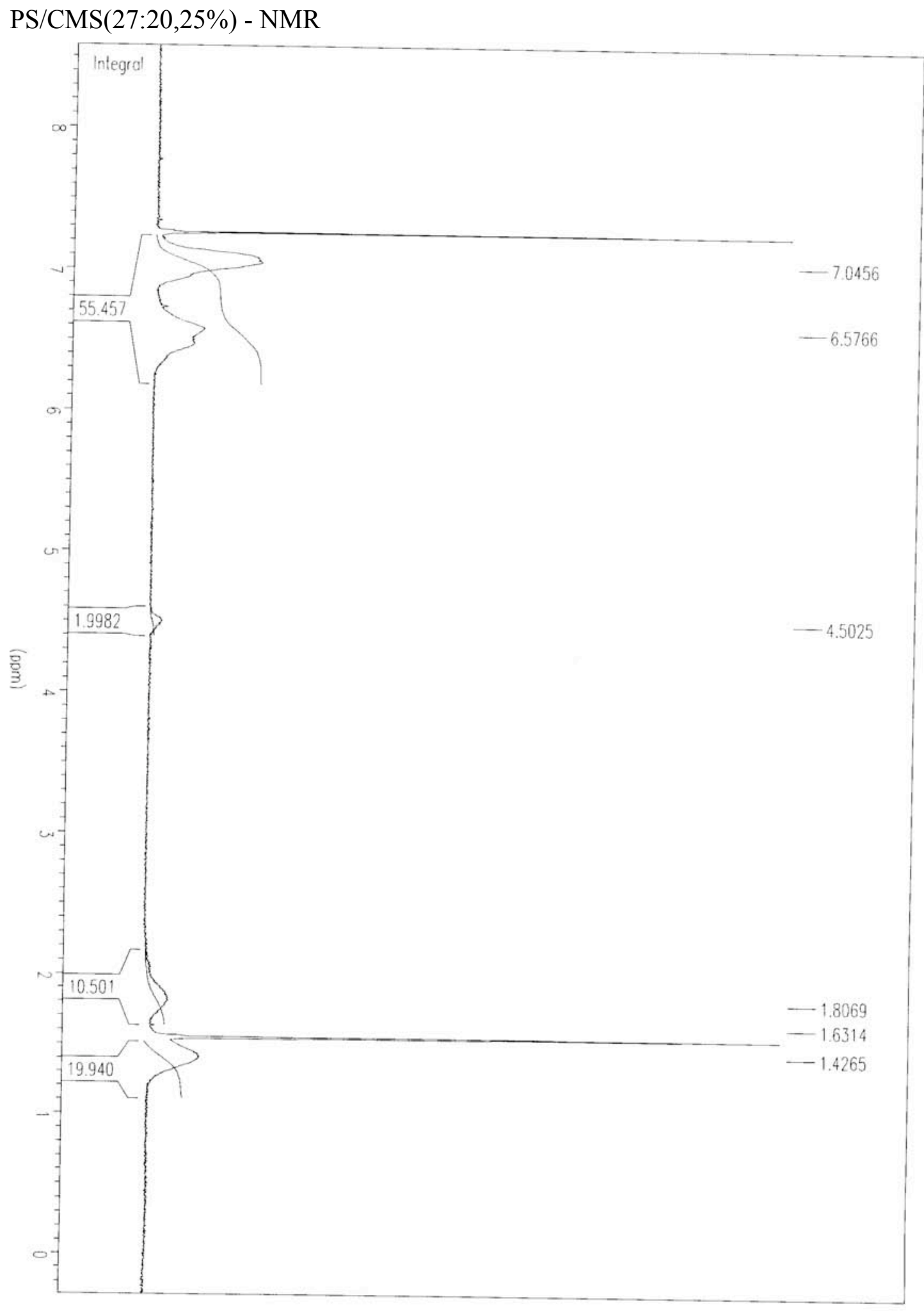




\section{PS/Anth(27:20,25\%) - NMR}

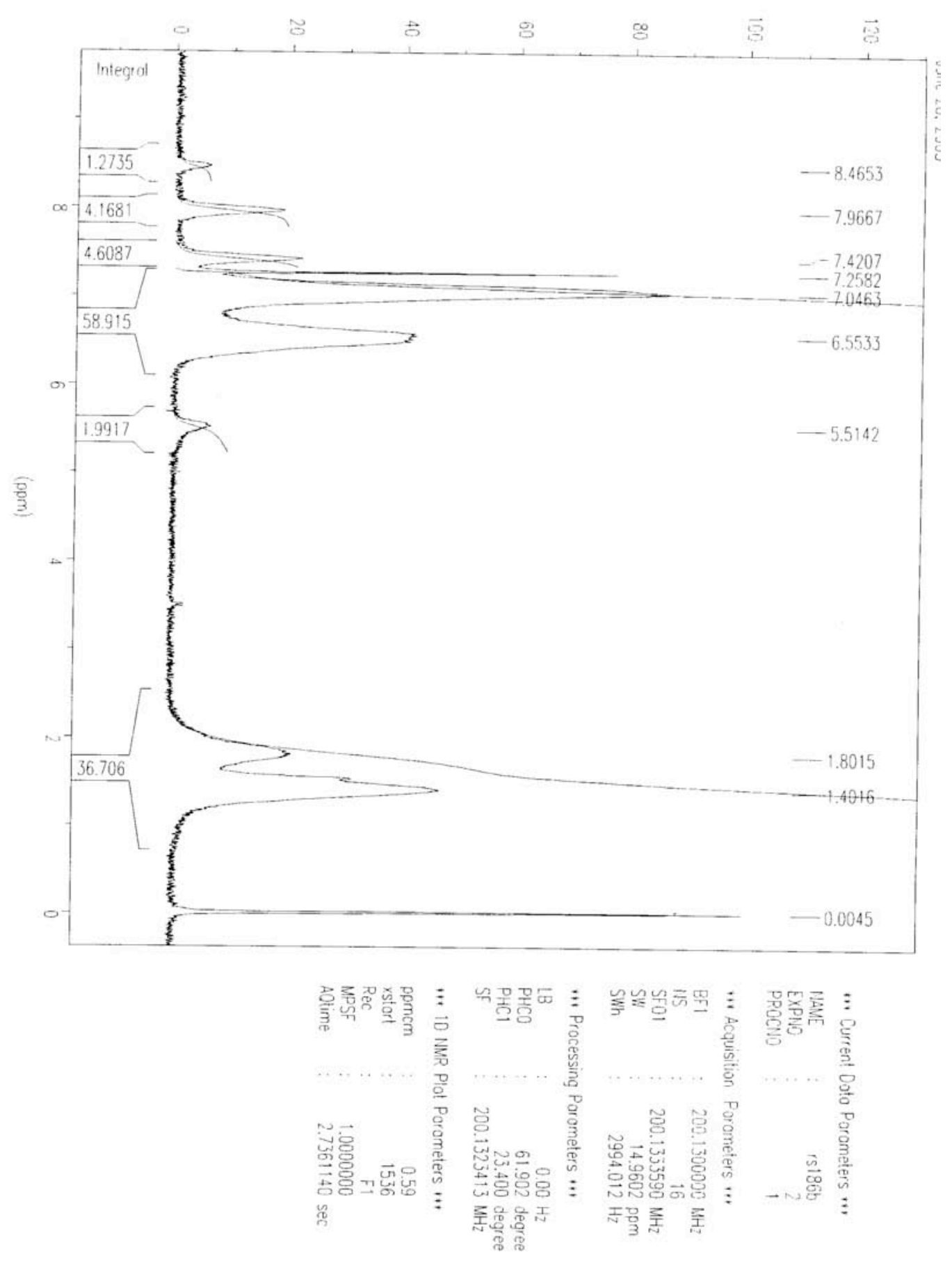




\section{PS/Pyr(27:20,25\%) - NMR}
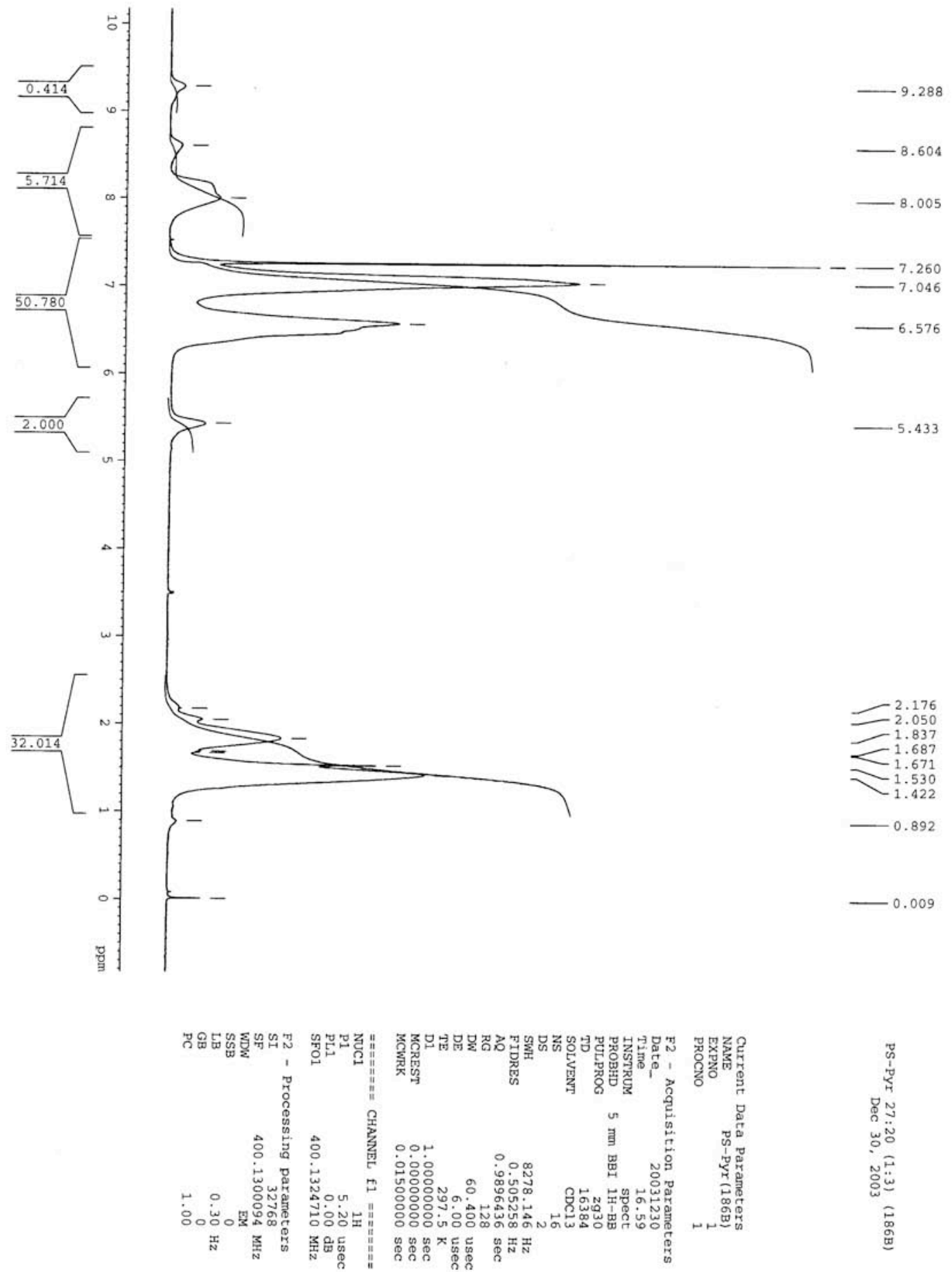

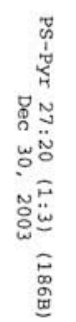




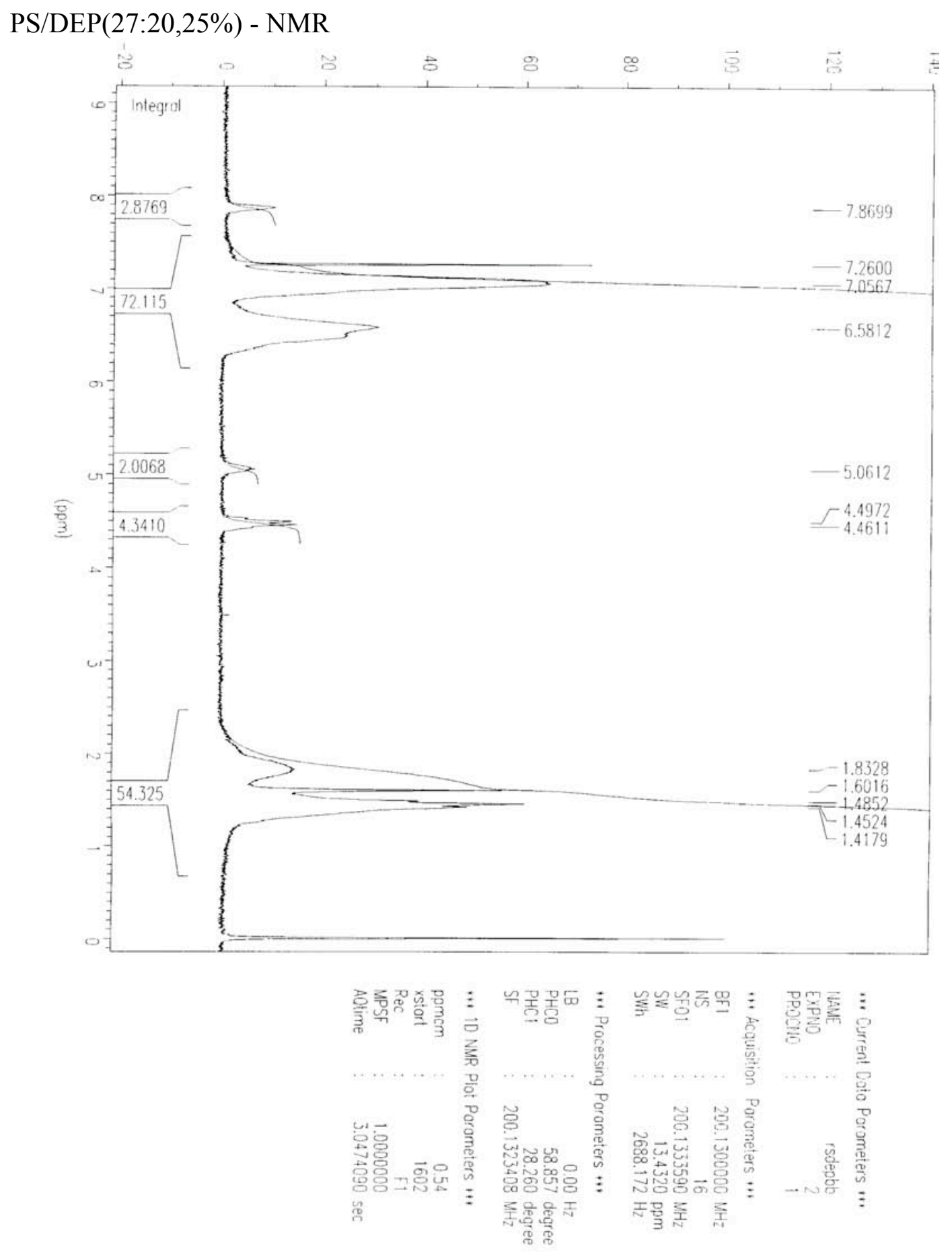


S30

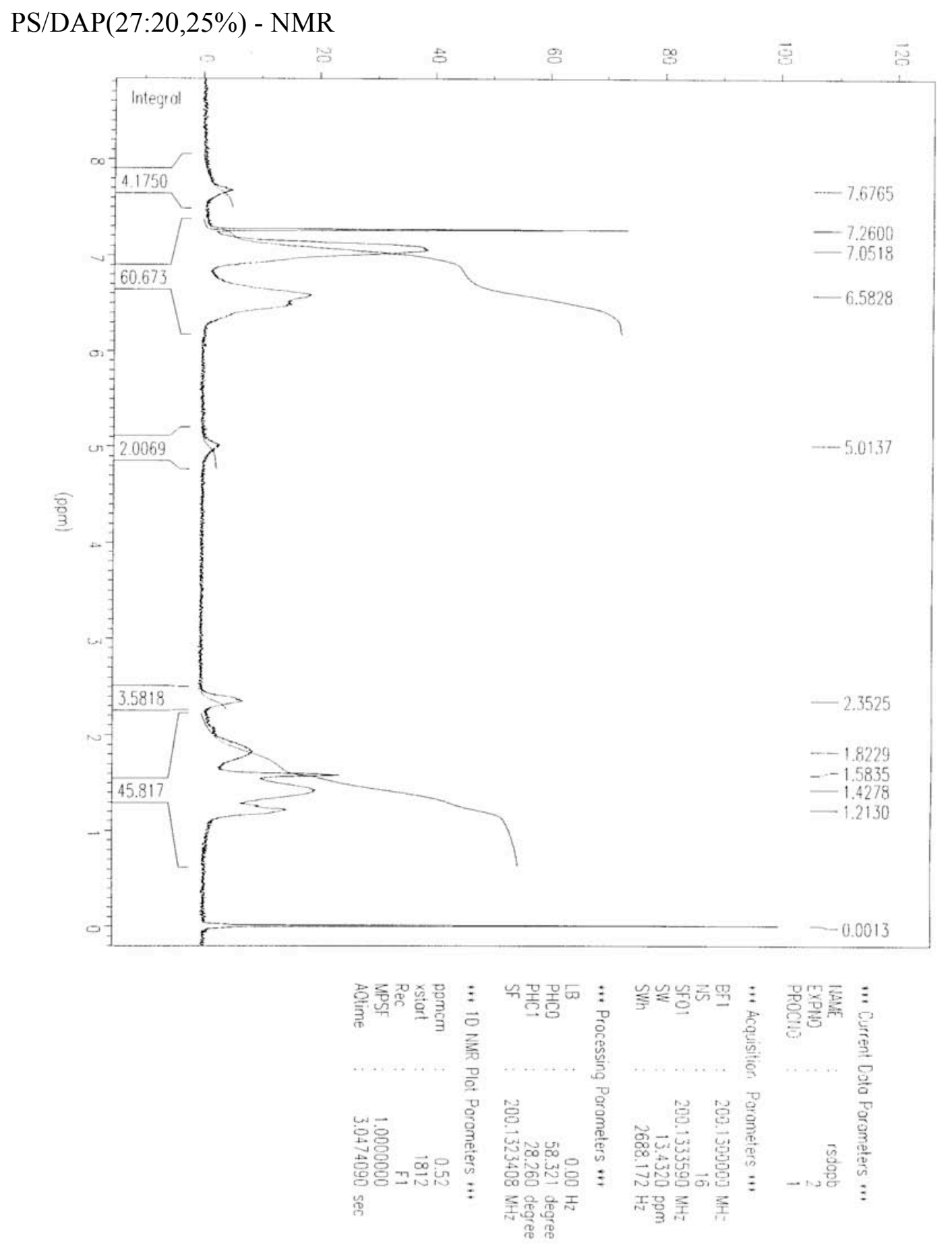


PS/CMS(27:23,20\%) - GPC

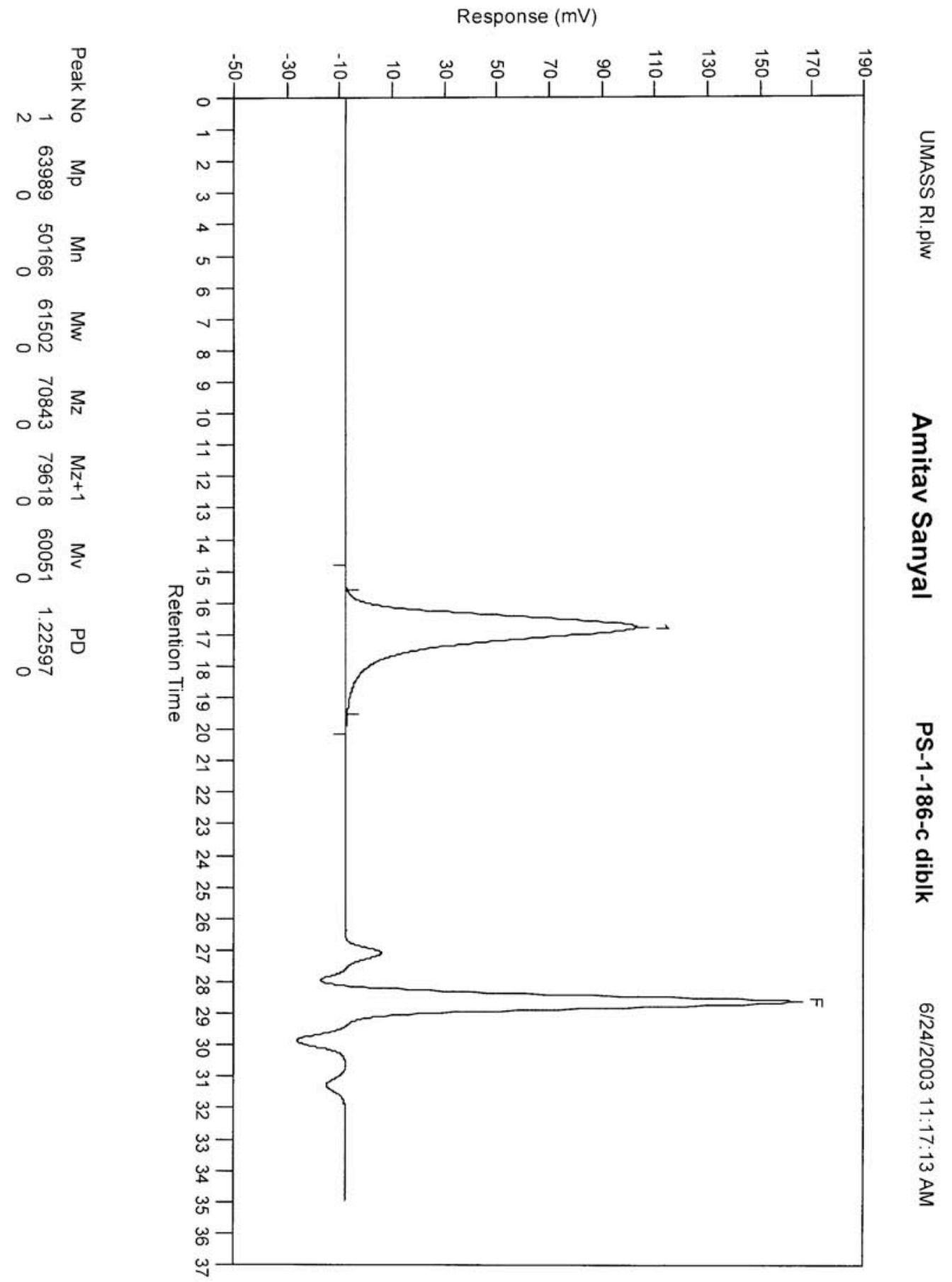




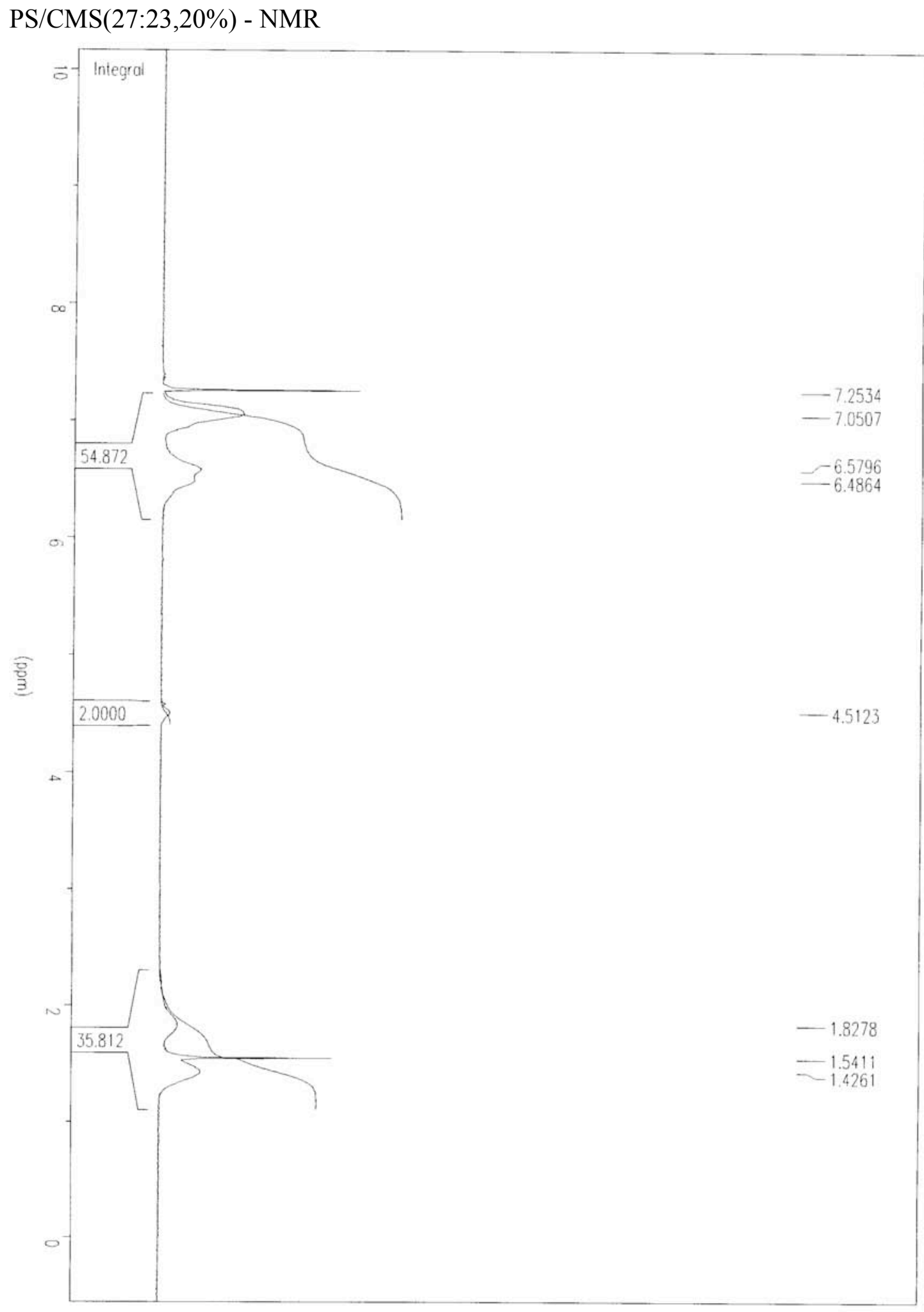


PS/Anth(27:23,20\%) - NMR

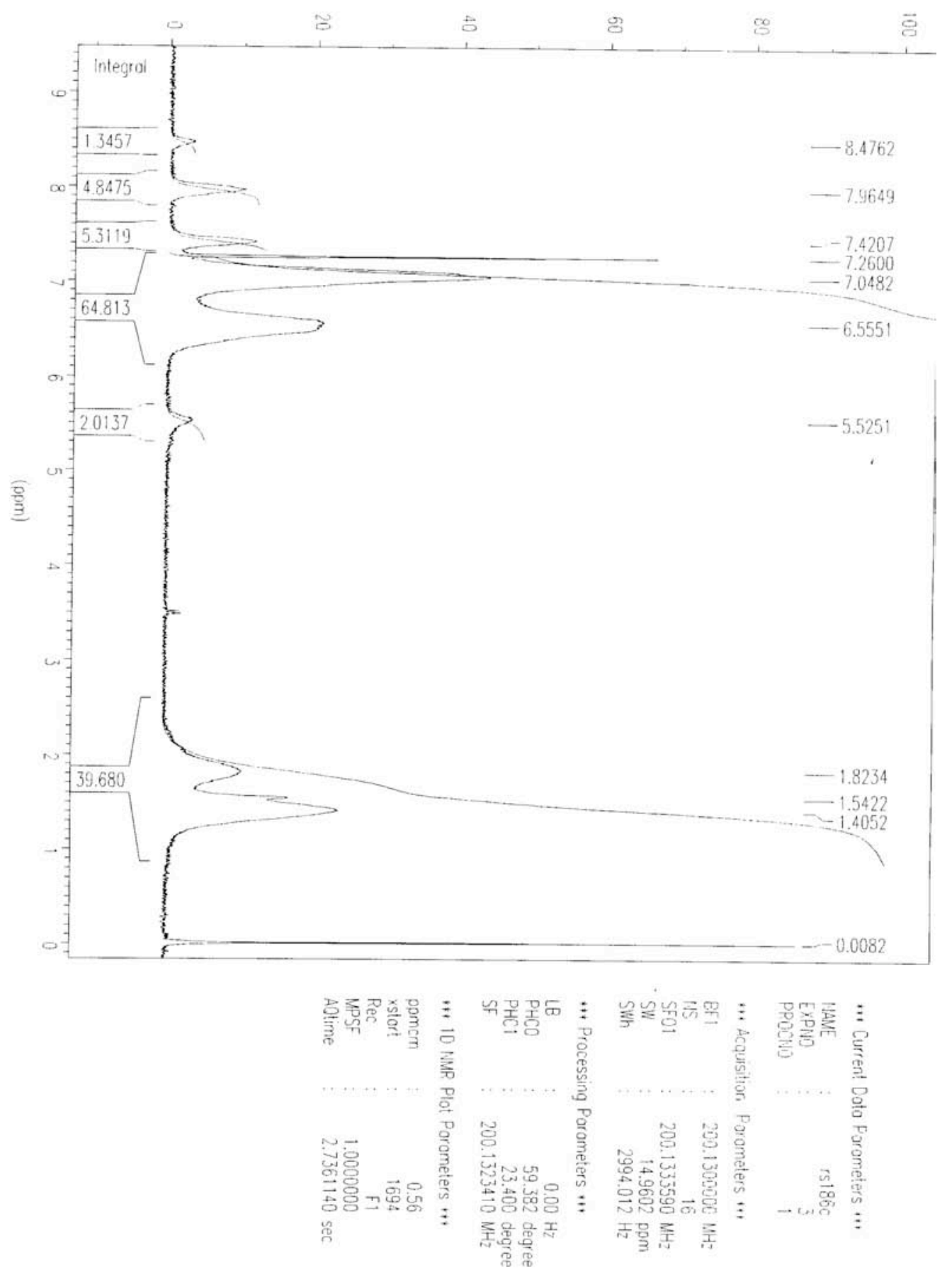




\section{PS/Pyr(27:23,20\%) - NMR}
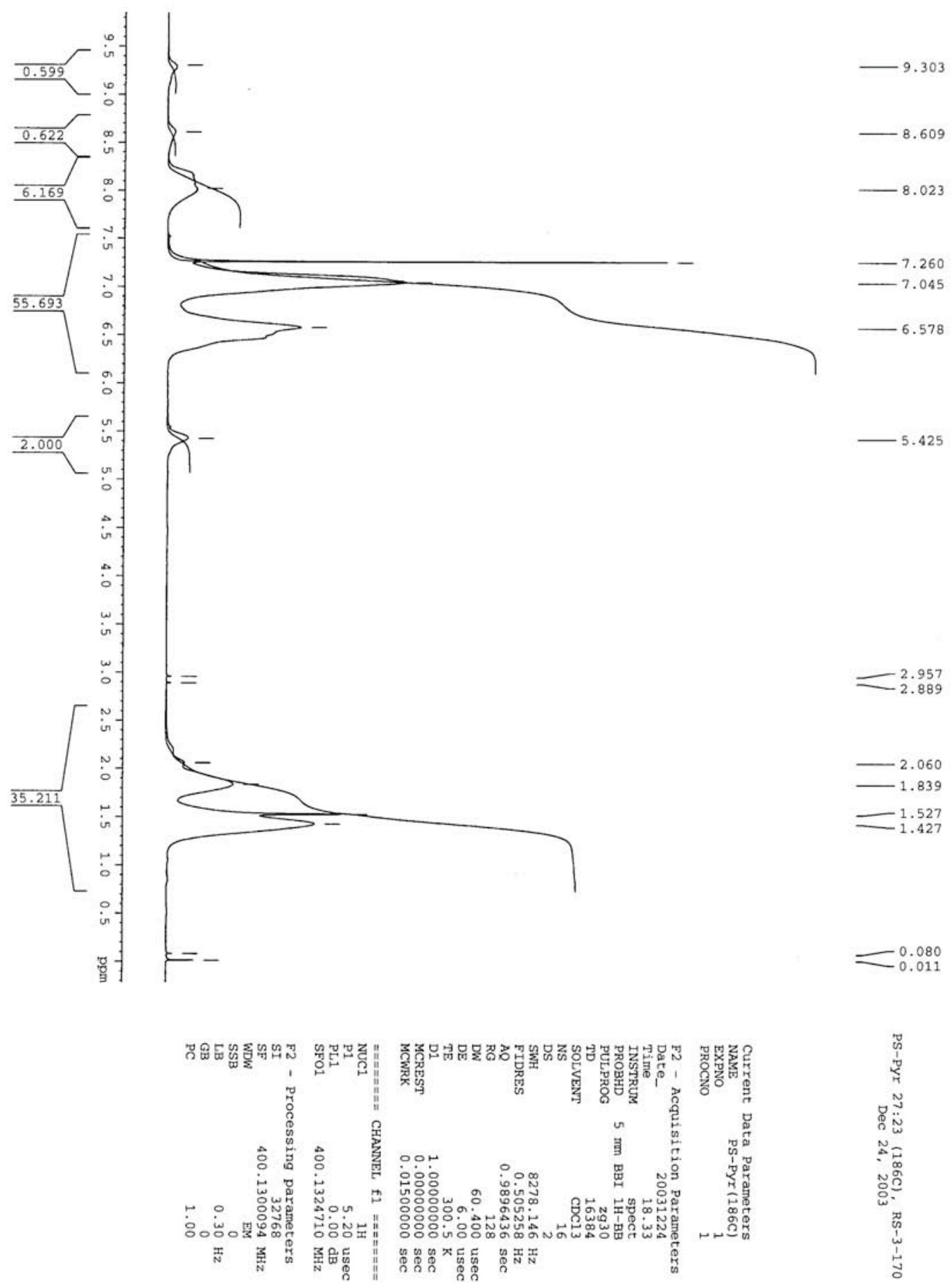

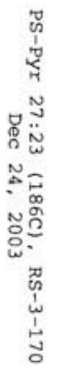


S35
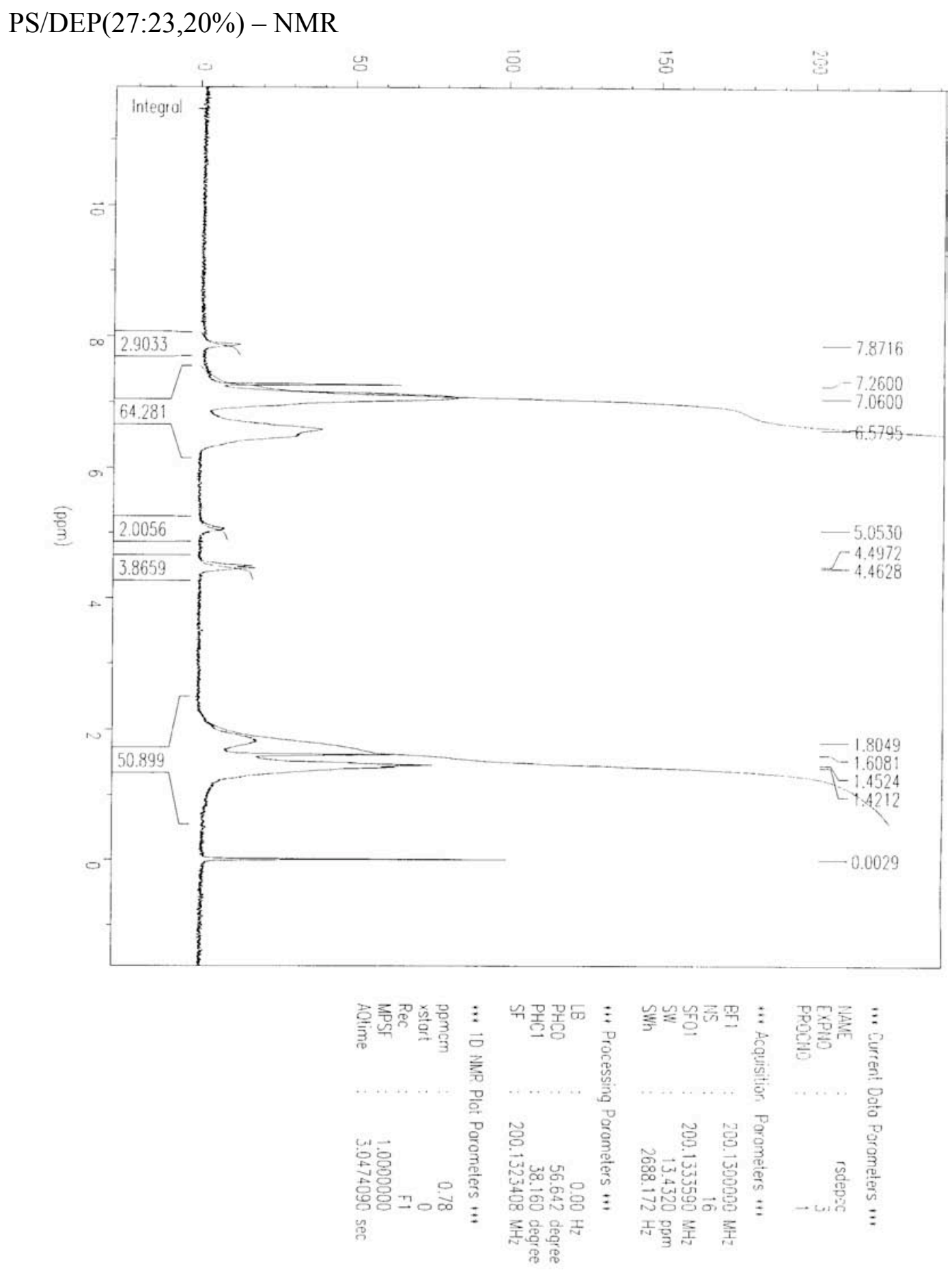
S36
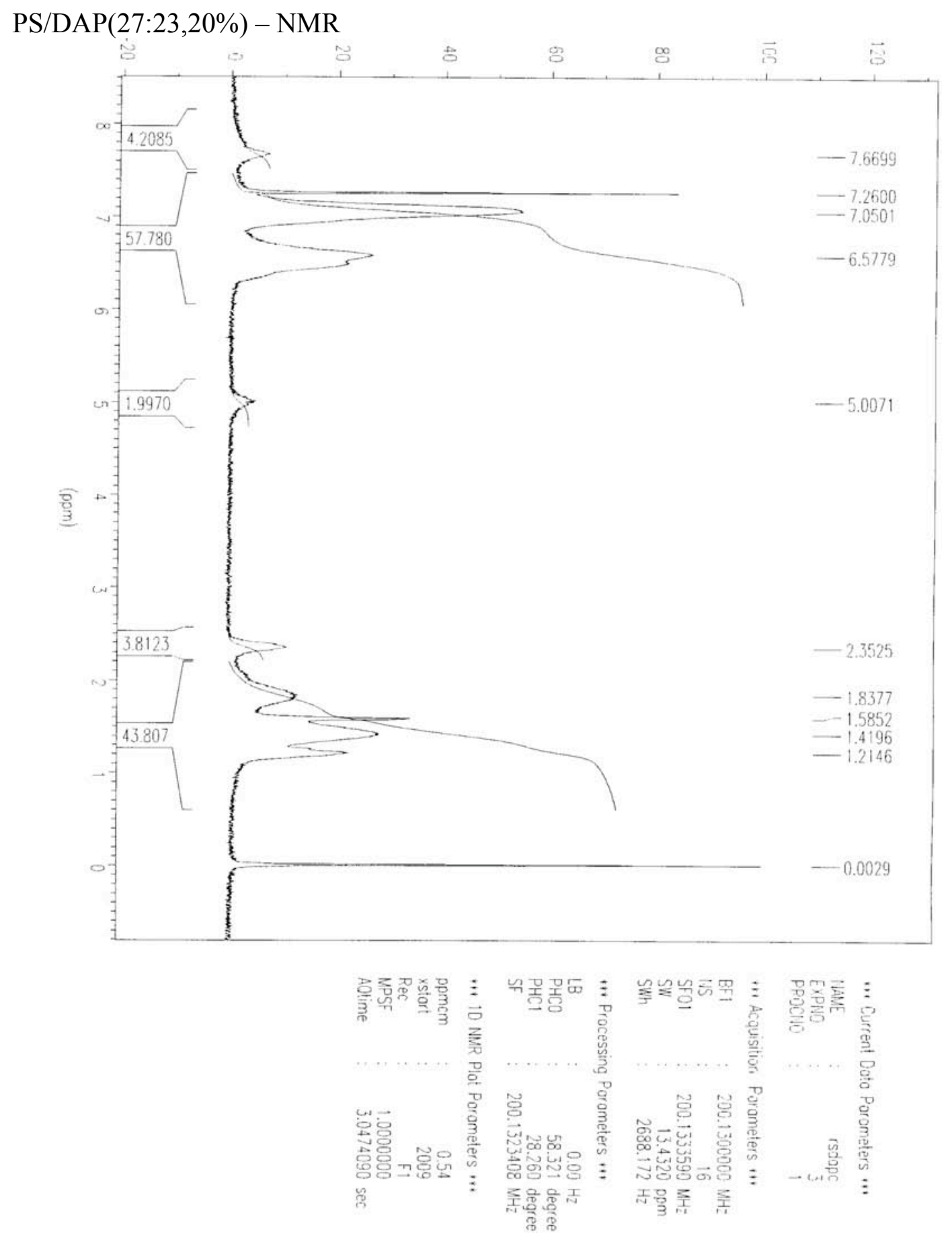
PS/CMS(27:26,22\%) - GPC

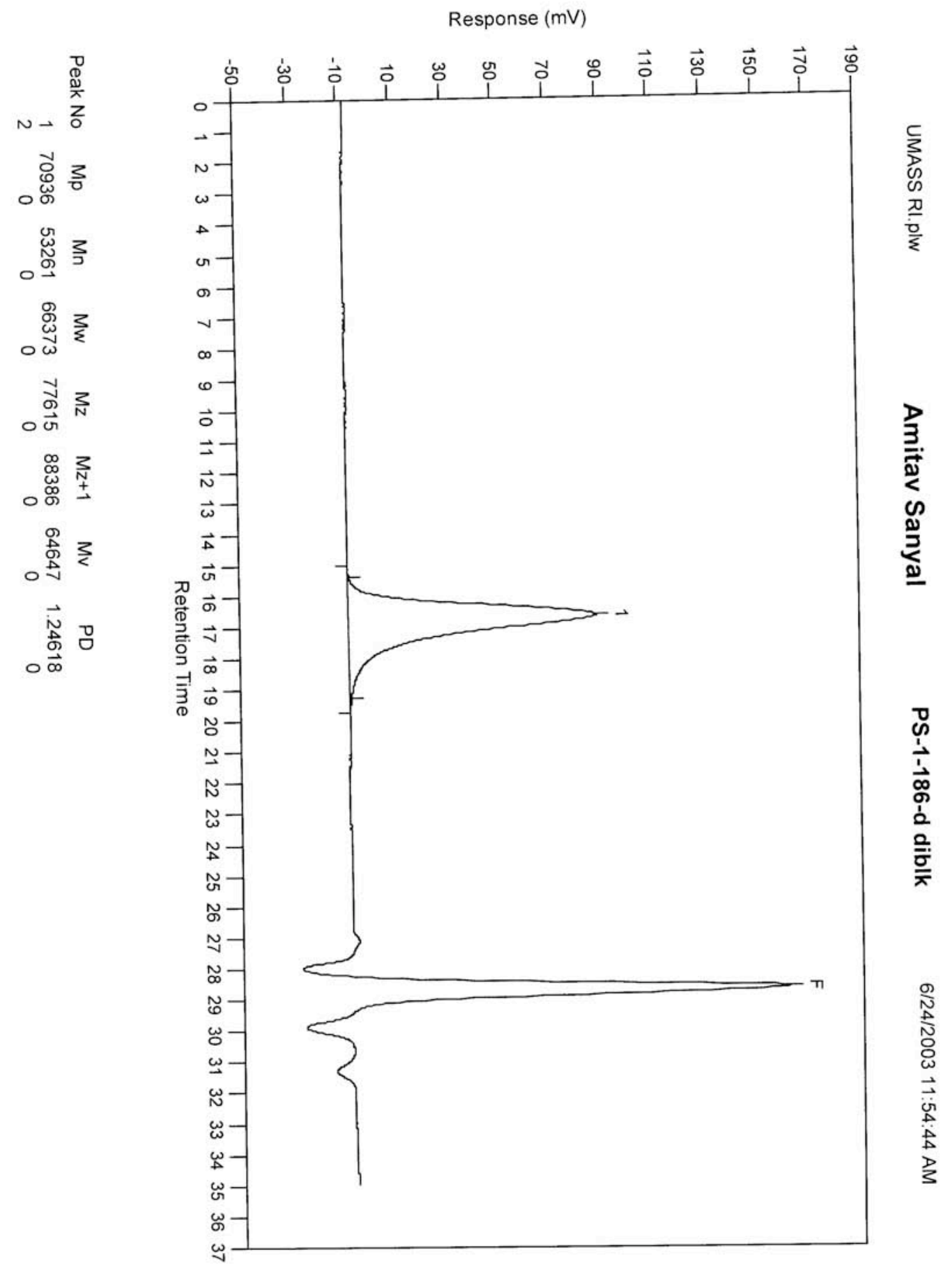




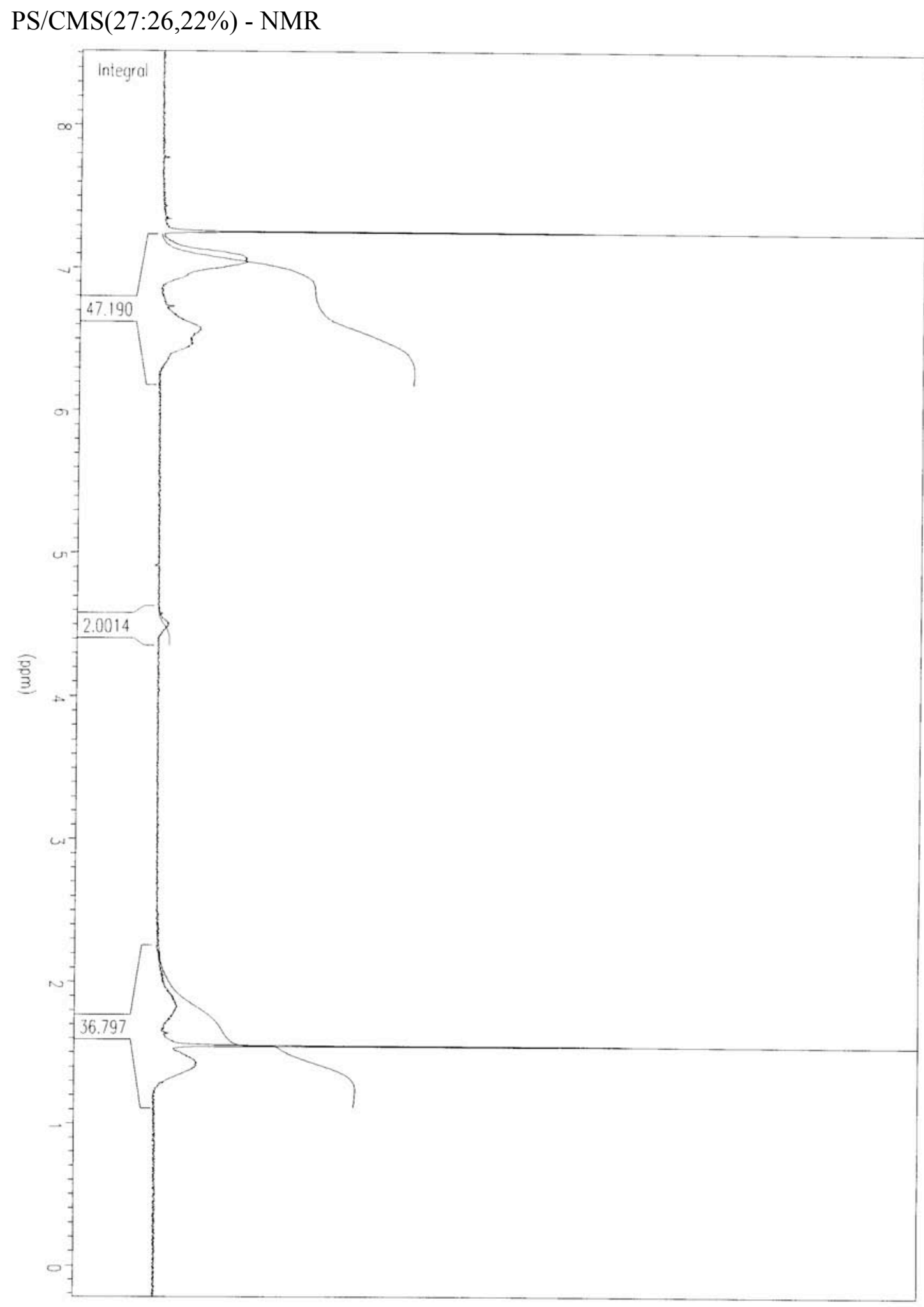


PS/Anth(27:26,22\%) - NMR

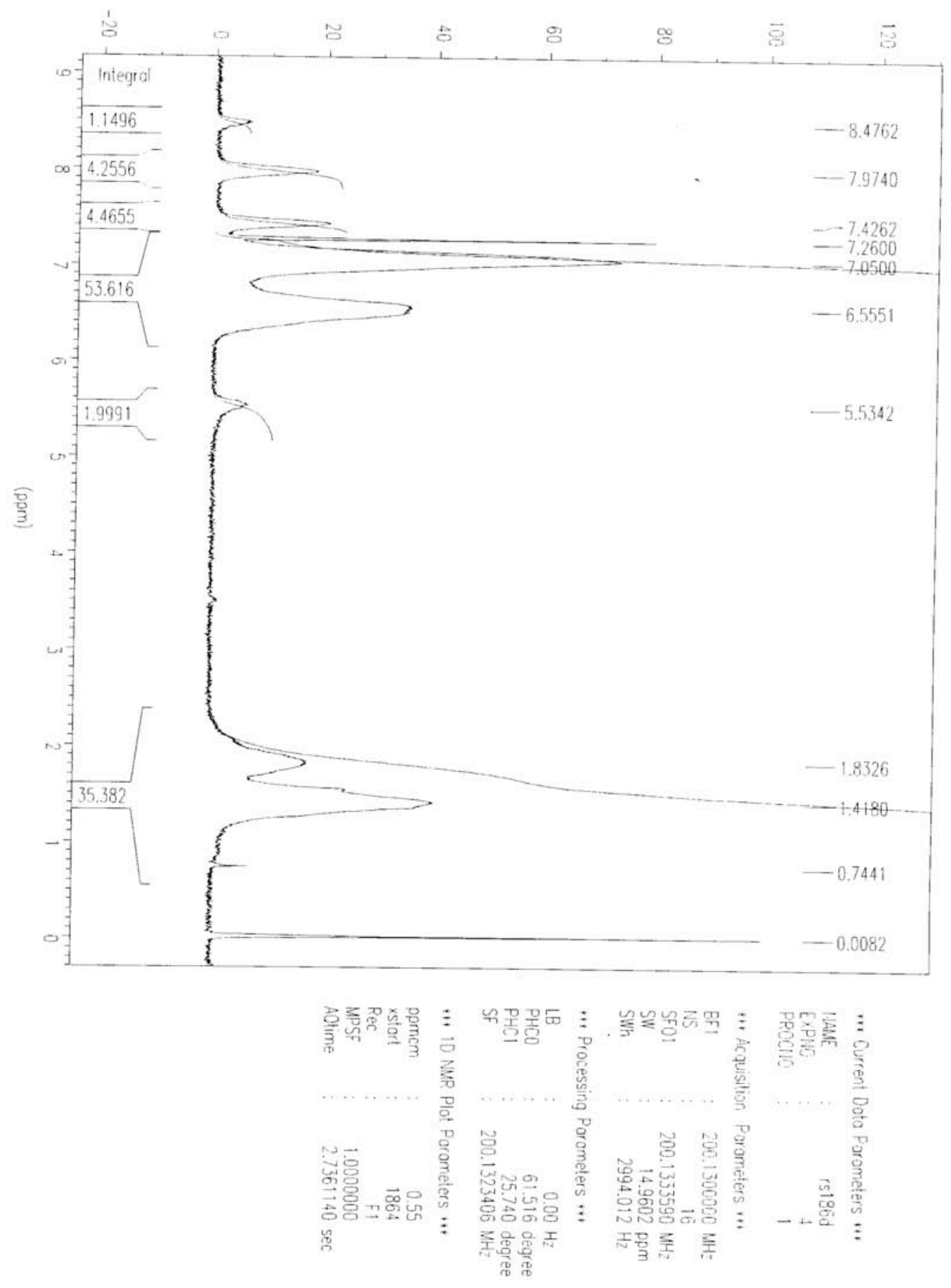


PS/Pyr(27:26,22\%) - NMR
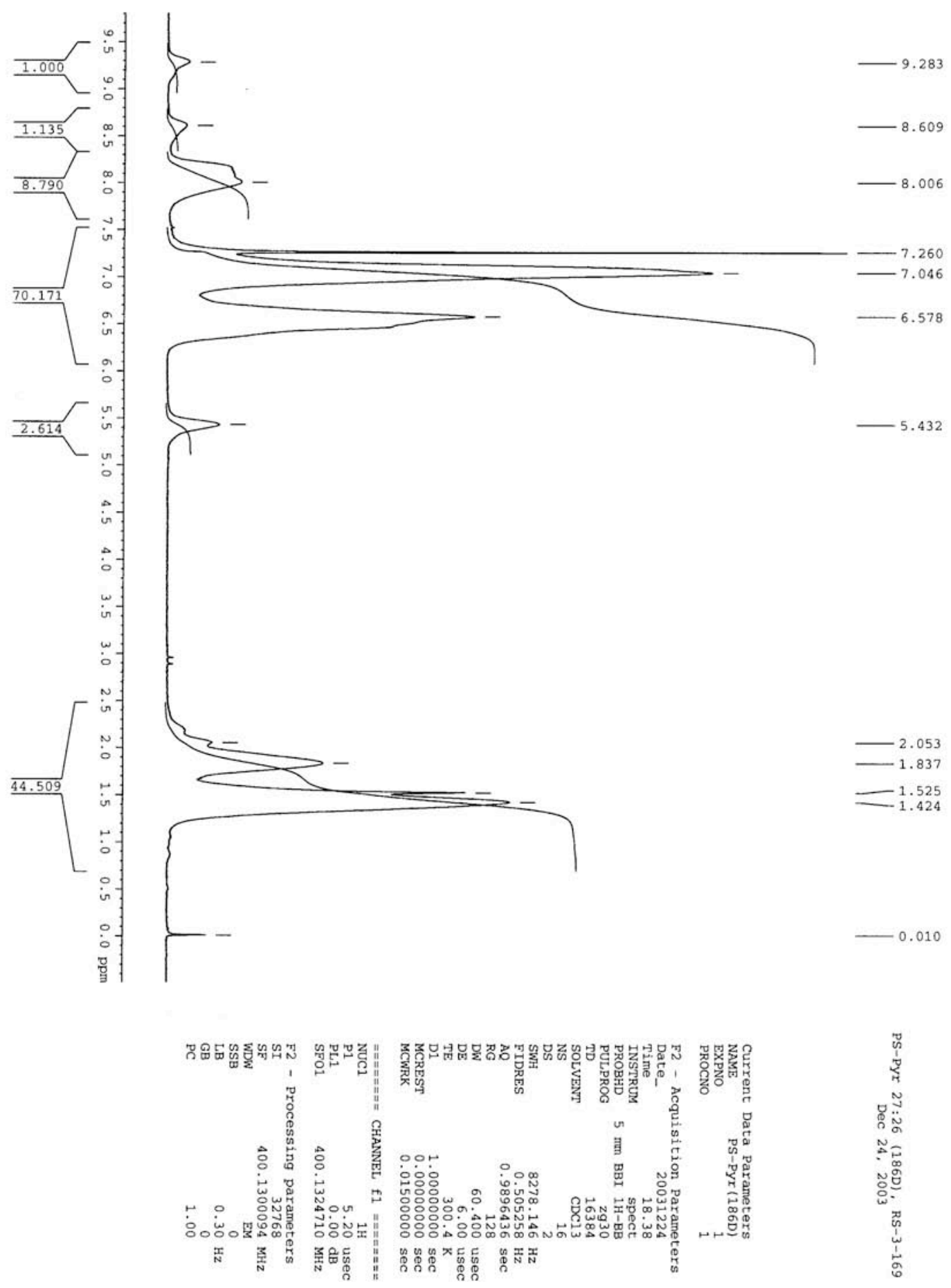
S41

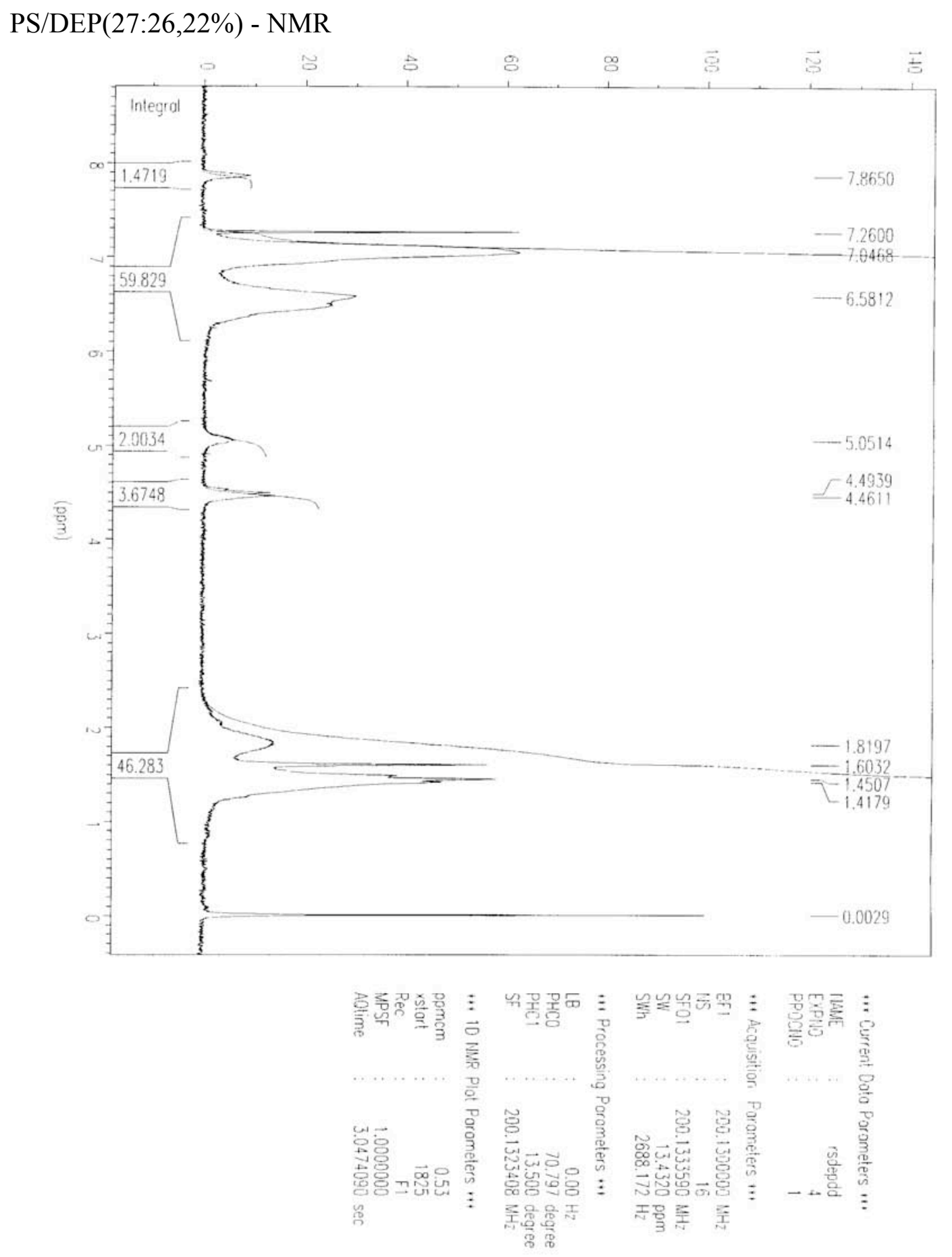


S42

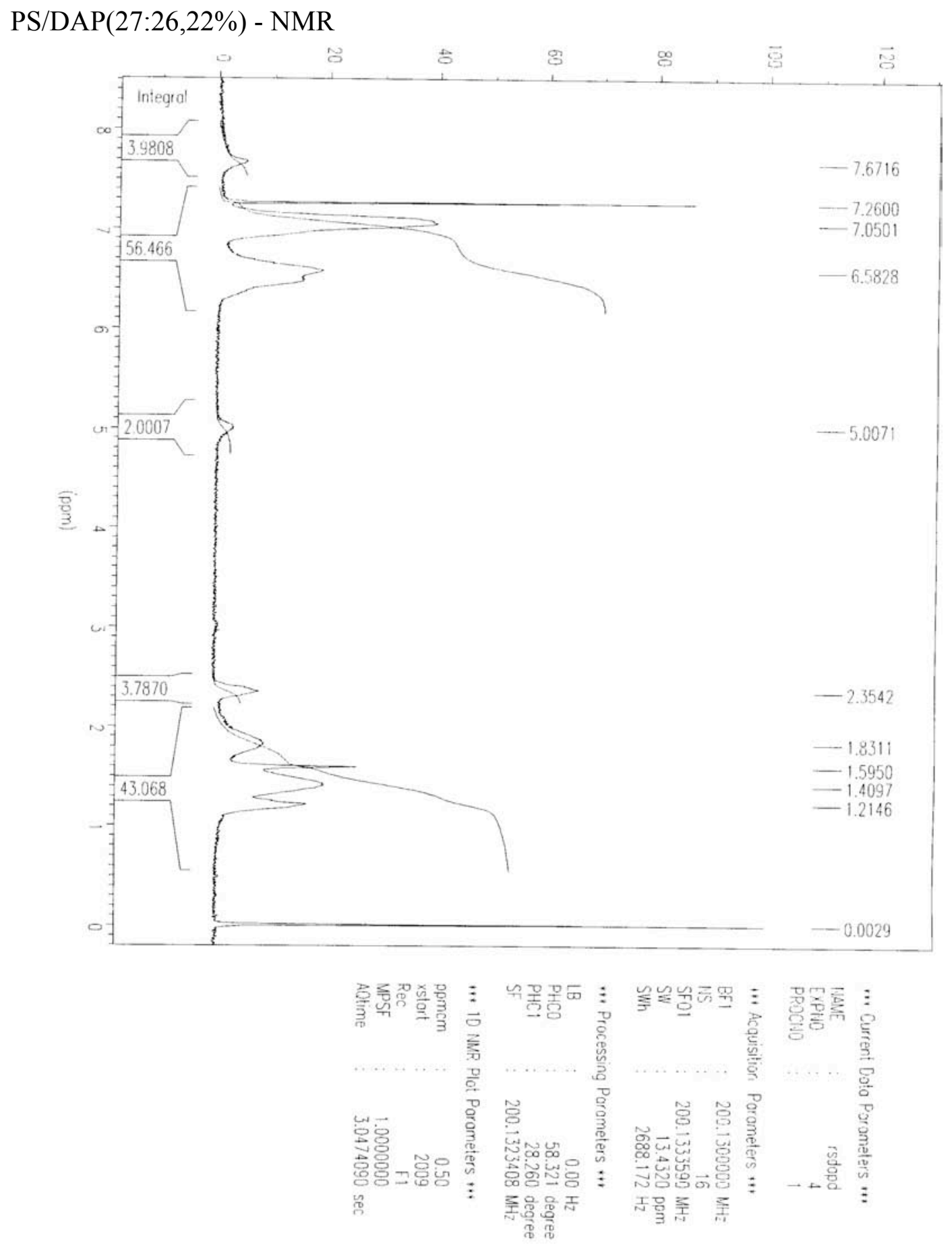

